\title{
Benefit:Risk Profile of Budesonide in Obstructive Airways Disease
}

\author{
Donald P. Tashkin ${ }^{1}$ (1) $\cdot$ Brian Lipworth ${ }^{2} \cdot$ Ralph Brattsand $^{3}$
}

Published online: 23 September 2019

(c) The Author(s) 2019

\begin{abstract}
Airway inflammation is a major contributing factor in both asthma and chronic obstructive pulmonary disease (COPD) and represents an important target for treatment. Inhaled corticosteroids (ICS) as monotherapy or in combination therapy with long-acting $\beta_{2}$-agonists or long-acting muscarinic antagonists are used extensively in the treatment of asthma and COPD. The development of ICS for their anti-inflammatory properties progressed through efforts to increase topical potency and minimise systemic potency and through advances in inhaled delivery technology. Budesonide is a potent, non-halogenated ICS that was developed in the early 1970s and is now one of the most widely used lung medicines worldwide. Inhaled budesonide's physiochemical and pharmacokinetic/pharmacodynamic properties allow it to reach a rapid and high airway efficacy due to its more balanced relationship between water solubility and lipophilicity. When absorbed from the airways and lung tissue, its moderate lipophilicity shortens systemic exposure, and its unique property of intracellular esterification acts like a sustained release mechanism within airway tissues, contributing to its airway selectivity and a low risk of adverse events. There is a large volume of clinical evidence supporting the efficacy and safety of budesonide, both alone and in combination with the fast- and long-acting $\beta_{2}$-agonist formoterol, as maintenance therapy in patients with asthma and with COPD. The combination of budesonide/formoterol can also be used as an as-needed reliever with anti-inflammatory properties, with or without regular maintenance for asthma, a novel approach that is already approved by some country-specific regulatory authorities and currently recommended in the Global Initiative for Asthma (GINA) guidelines. Budesonide remains one of the most well-established and versatile of the inhaled anti-inflammatory drugs. This narrative review provides a clinical reappraisal of the benefit:risk profile of budesonide in the management of asthma and COPD.
\end{abstract}

\section{Introduction}

Chronic airway inflammation is a characteristic feature of asthma and chronic obstructive pulmonary disease (COPD), and is therefore an important target for treatment $[1,2]$. Use of glucocorticosteroids (corticosteroids) has been investigated in both conditions [3-7], with the first successful treatment of asthma with an oral corticosteroid (OCS) reported in $1950[3,8]$. However, although highly effective, long-term use of OCS was soon found to be associated with serious

Donald P. Tashkin

dtashkin@mednet.ucla.edu

1 Division of Pulmonary and Critical Care Medicine, Department of Medicine, David Geffen School of Medicine, University of California Los Angeles, 10833 Le Conte Avenue, Los Angeles, CA 90095-1690, USA

2 Scottish Centre for Respiratory Research, Division of Molecular and Clinical Medicine, Ninewells Hospital and Medical School, Dundee, UK

3 Experimental Pharmacology, Budera Company, Kristinehamn, Sweden adverse effects, including osteoporosis, diabetes, Cushing's syndrome, acne, skin thinning and bruising [8].

Following early trials of inhalation with various dermal hydrocortisone formulations $[9,10]$, second-and third-generation dermal steroids were developed by medicinal chemists who focused on increasing potency through addition of the halogens chlorine or fluorine [11], leading to the first successful inhaled corticosteroid for the treatment of asthma in 1972: beclomet(h)asone dipropionate (BDP) [5]. However, BDP was selected on the basis of its high topical efficacy on the skin and was not specifically optimised to reduce its systemic risks when absorbed via other routes. In contrast, given the known systemic side effect liability of second- and third-generation halogenated steroids, budesonide (developed in the same period as the BDP inhalation findings) was screened primarily for improved topical selectivity [12, 13]. Budesonide was found to have a better topical selectivity than that of BDP, fluocinolone acetonide, flunisolide (FLU) and triamcinolone acetonide (TA) [12, 13]. Thus, budesonide was the first topical corticosteroid selected for improved local selectivity, and its rapid uptake into tissue made it a good prospect for inhalation therapy. This was the 


\section{Key Points}

Inhaled corticosteroids are the cornerstone of current treatment for asthma and are also widely used in combination with a long-acting $\beta_{2}$-agonist with or without a long-acting muscarinic antagonist in the management of patients with moderate-to-severe chronic obstructive pulmonary disease.

Budesonide is a long-established inhaled corticosteroid and its unique molecular structure and pharmacokinetic/ pharmacodynamic properties underpin its rapid efficacy and favourable safety profile.

Budesonide may be used as maintenance therapy in patients with moderate-to-severe asthma and is recommended in global asthma management guidelines for use in combination with the bronchodilator formoterol as an as-needed reliever with anti-inflammatory properties, with or without regular maintenance therapy.

basis for its development for asthma and eventual use in the treatment of COPD.

This clinical utility has given further impetus to the development of newer inhaled corticosteroids (ICS), and FLU, fluticasone propionate (FP), ciclesonide (CIC), mometasone furoate $(\mathrm{MF})$, and fluticasone furoate $(\mathrm{FF})$ have been approved since the introduction of beclometasone and budesonide. These newer compounds were designed primarily for enhanced lipophilicity, which prolonged intraluminal airway retention time with the aim of achieving efficacy with oncedaily dosing. However, this approach also introduced potential issues around longer localised airway immunosuppression, potentially enhancing the risk of pneumonia and other respiratory infections [14]. The raised lipophilicity also prolongs the terminal half-life in the systemic circulation, which increases the risk of systemic adverse effects [15-17].

Today, ICS are recommended in guidelines as the cornerstone of pharmacotherapy for patients with persistent asthma across all severities, and also in combination with a long-acting $\beta_{2}$-agonist (LABA) for patients with moderate to severe asthma [18]. ICS are considered by the Global Asthma Network guidance as the first-line asthma preventer for patients with persistent or frequent symptoms, and in combination with LABA (ICS/LABA) are envisaged to have an ever-increasing role in the treatment of asthma [19]. Indeed, two ICS and one ICS/LABA combination are listed on the World Health Organization's Model List of Essential Medicines [19]. Furthermore, they remain the only class of anti-asthma drug proven to reduce asthma deaths [20]. In COPD, ICS are recommended in combination with LABA by current guidelines for patients with moderate-to-very severe COPD at high risk of exacerbations, since this combination improves both symptoms and lung function and reduces exacerbation risk [21].

In this narrative review, based on the authors' collective expertise, we provide a clinical reappraisal of the benefit:risk profile of budesonide in the management of asthma and COPD, after a brief overview of the pharmacodynamics of ICS.

\section{Brief Overview of Inhaled Corticosteroids (ICS) Pharmacodynamics}

\subsection{Mechanisms of Action of ICS in Asthma and Chronic Obstructive Pulmonary Disease (COPD)}

ICS diffuse through cell membranes and subsequently bind to the glucocorticoid receptor (GCR). The GCR, which is believed to share a common ancestral receptor type with the mineralocorticoid and progesterone receptors (MR and PR), is present in the cytoplasm of most human cell types, bound to HSP90 chaperone proteins [22-24]. Binding results in dissociation of HSP90 and formation of an activated GCR-corticosteroid complex. Subsequent translocation across the nuclear membrane, interaction with other nuclear transcription factors, and homodimeric binding to specific deoxyribonucleic acid (DNA) sequences allow the regulation of gene transcription and protein synthesis [22, 23]. In the airways and lungs, corticosteroids interact with the GCR following inhalation and absorption into airway mucosa and the tissues below.

Whereas most drugs have a narrow 'therapeutic window', corticosteroids can exert their effects over a broad concentration range [25]. This is due to the existence of multiple mechanisms of action. Broadly, the steroid-activated GCR can be viewed as a ligand-regulated transcription factor, which controls a very diverse set of genes. Most actions of corticosteroids are mediated by the pleiotropic effects of GCRs on multiple signalling pathways [23, 26, 27]. Three major classes of action relevant for control of asthma and COPD have been described: (1) directly regulating the expression of inflammatory genes encoding cytokines, chemokines, adhesion molecules, inflammatory enzymes, receptors and proteins by binding to positive or negative glucocorticoid response elements (GRE); (2) binding to and sequestering other transcription factors, such as nuclear factor (NF)-кB; and (3) directing DNA three-dimensional histone protein binding architectures via the counterbalanced activity of histone acetyltransferases and histone deacetylases, thus regulating access to the transcriptional gene machinery [28]. 
Microarray analyses of cultured airway epithelial cells have enabled detailed mapping of genes affected by budesonide treatment [29]. A single, high-dose budesonide inhalation led to $\mathrm{a} \geq 2$-fold increase in the expression of 46 genes in bronchial biopsy samples within $6 \mathrm{~h}$ [30]. Upregulated genes included those inhibiting NF- $\mathrm{\kappa B}$ and AP-1, the dualspecificity phosphatase- 1 that controls activated mitogenactivated protein kinases (MAPK), and inhibitors of G-protein coupled receptors and T-cell chemotaxis. There were also 10 downregulated genes whose expression decreased by at least $50 \%$ following budesonide inhalation, including genes for chemokines, metalloproteases and Toll-like receptors.

Another potential mechanism of action of ICS involves protection against oxidative or viral damage to the epithelial barrier function. In cultured human epithelial cell lines, budesonide protected barrier function significantly more effectively than FP in response to cigarette smoke extract, possibly due to attenuation of epidermal growth factor receptor-dependent glycogen synthase kinase-3 $\beta$ phosphorylation [31].

However, there are also some faster, non-genomic mechanisms that inhibit the production of mediators associated with inflammatory cells in the airways $[22,26]$, such as GCR-dependent inhibition of the MAPK pathway [32, 33]. Rapid change in airway blood flow is a non-genomic parameter that reflects bronchial vascular response to ICS. Corticosteroids inhibit organic cation transporters (OCT), such as OCT-3, expressed by the vascular smooth muscle cells, resulting in an increase of adrenergic agonists at $\alpha$-adrenergic receptor sites [34]. ICS can therefore reduce the airway hyperaemia that is both a manifestation of inflammation and a contributory factor to further inflammation. Budesonide has been shown to rapidly reduce airway hyperaemia, and was significantly more potent in this respect than $\mathrm{BDP}$, and more potent than FP in asthmatic subjects in one comparative study [35].

\subsection{Corticosteroid Chemical Structure-Activity Relationship}

All corticosteroids consist of a hydrogenated cyclopentanoperhydrophenanthrene ring system, with three cyclohexane rings and one cyclopentane ring [36] and a range of different substituents. It is the nature and position of these substitutions that determine differences in their potency and clinical efficacy (Fig. 1) [37]. Key positions that affect potency are halogenation of the 6 and 9 positions [38], while R-substitution at the $16 \alpha$ and $17 \alpha$ positions affects lipophilicity. Also, R-substitution at the 17 position affects the glucocorticoid potency. Budesonide is a non-halogenated ICS that has lipophilic substitutions at the $16 \alpha$ and $17 \alpha$ positions and a hydroxyl group at the C21 position (Fig. 1) [13, 38].
Pharmacological and metabolic studies have shown that the non-symmetrical acetal substitution in the $16 \alpha$ and $17 \alpha$ positions optimises the ratio of topical to systemic activity [12, $38,39]$. After systemic uptake, budesonide's non-symmetrical acetal group can be split by liver enzymes, resulting in metabolites with much lower receptor affinity, which does not occur to the same extent for the symmetrical acetals of the $16 \alpha, 17 \alpha$-acetonide glucocorticoids (e.g. FLU, TA) [40]. This, together with further biotransformation routes, improves the systemic tolerability of budesonide and enables dose escalation when required $[41,42]$.

\subsection{Factors Affecting Lung Deposition}

The clinical benefits of an inhaled therapy depend on drug particles being deposited in the airways/lungs, rather than swallowed or exhaled. Particles between $1-5 \mu \mathrm{m}$ in diameter are the optimal size for deposition in the central and peripheral airways [45, 46]. If particles $<1 \mu \mathrm{m}$ are not exhaled again [45], they may be deposited in the alveoli and rapidly absorbed into the systemic circulation $[47,48]$ while larger particles tend to impact on the oropharynx rather than reaching the central or peripheral airways/lung [46]. Along with particle size, lung deposition also depends on factors such as the velocity at which the particles are delivered and, with the dry powder inhaler (DPI), the peak inspiratory flow rate and internal resistance of the device [46].

\section{Development of Budesonide}

In the 1960 s, researchers at the Swedish pharmaceutical company Bofors Nobel-Pharma (a project later incorporated into Astra $\mathrm{AB}$ ) designed a novel series of potent non-symmetrical $16 \alpha, 17 \alpha$-acetal corticosteroids [12, 13]. Using new functional screening models for local selectivity, including human forearm skin blanching potency tests, the lead compound, budesonide, was found to have a topical selectivity several-fold better than BDP and other dermal steroids. The first patent application was filed in 1972 and budesonide was selected as a candidate drug by Astra AB in 1974 , with asthma as the primary indication. Positive initial study results led to the approval of budesonide in 1981 for daily maintenance treatment for asthma (Fig. 2) [49].

In the first studies in asthma, budesonide was delivered via a pressurised metered-dose inhaler (pMDI) [6, 50-55]. Dose-dependent improvements in peak expiratory flow (PEF) were demonstrated for daily doses of 400-1600 $\mu \mathrm{g}$ [6] and, during the 1990s, the results from studies with budesonide in asthma supported early intervention with ICS after initial onset of symptoms [56-58]. This was shown to improve asthma control and potentially to prevent progression to chronic irreversible airway obstruction $[59,60]$. 


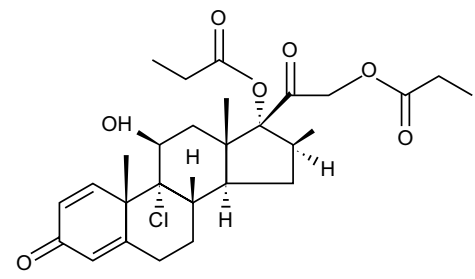

Beclomet(h)asone dipropionate

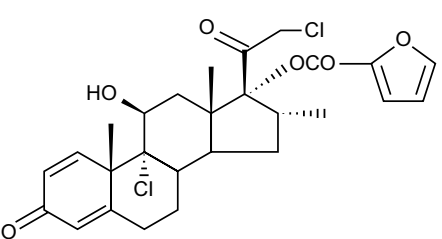

Mometasone furoate

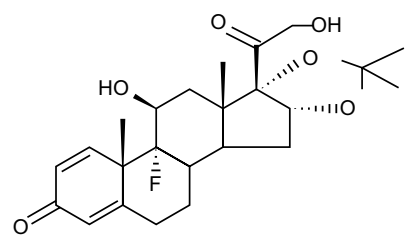

Triamcinolone acetonide

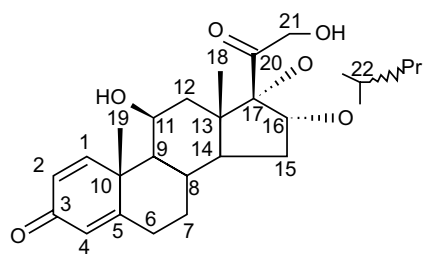

Budesonide

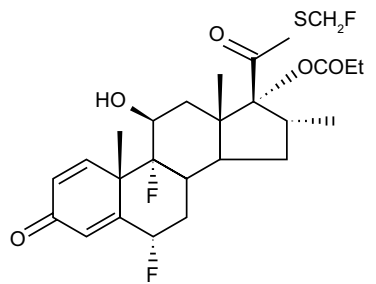

Fluticasone propionate

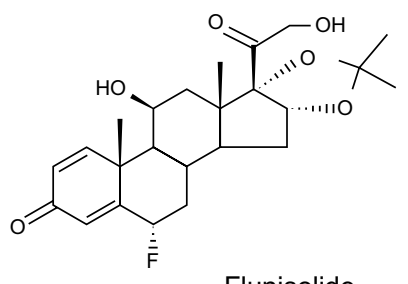

Flunisolide<smiles>C[C@H]1CC2C3C[C@H](F)C4=CC(=O)C=CC4(C)[C@@]3(F)C(O)CC2(C)[C@H]1C(=O)SCF</smiles>

Fluticasone furoate

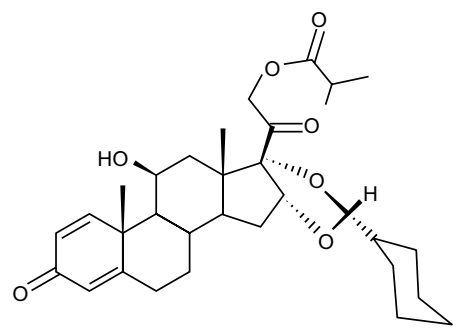

Ciclesonide<smiles>CC12C=CC(=O)C=C1CCC1C2C(O)CC2(C)C1CC[C@@]2(O)C(=O)CO</smiles>

Prednisolone
Fig. 1 The structures of inhaled corticosteroids [25]. Most ICS are pionate and ciclesonide are prodrugs that require conversion to the active state by on-site hydrolysis in airway/lung tissue. This is due to administered as active compounds; however, beclometasone dipro-

the fact they have a pre-existing ester at position $\mathrm{C} 21$. Ciclesonide is activated to desisobutyryl-ciclesonide (des-CIC), and beclometasone dipropionate to beclometasone-17-monopropionate (BMP) [43, 44]. Adapted with permission from Daley-Yates [25]

daily dose), and was well tolerated in both studies. A nebuliser suspension (Respules ${ }^{\circledR}$ ) was subsequently developed for the treatment of very young children or other patients who were unable to use a handheld inhaler effectively [65].

Budesonide is currently available as a single-drug formulation in the Flexhaler ${ }^{\circledR}$ (in the US) or Turbuhaler ${ }^{\circledR}$ DPI (outside of the US), in the Respules ${ }^{\circledR}$ nebuliser suspension [65], and in combination with formoterol as a pMDI or DPI. Budesonide drug particles delivered via any of these technologies are within the optimal range of 1-5 $\mu \mathrm{m}$ [46]. Generic formulations are now available in some countries.

\section{Properties of Budesonide} dosing feasible. Dose-dependent improvements in lung function were observed in two 12-week, randomised, placebocontrolled studies of budesonide Turbuhaler ${ }^{\circledR}$ in adults [63] or children [64] with moderate-to-severe persistent asthma. Budesonide twice daily via Turbuhaler ${ }^{\mathbb{B}}$ was significantly more effective than placebo, even at low doses $(200 \mu \mathrm{g}$ total
The development of ICS subsequent to budesonide aimed to improve once-daily efficacy by enhancing their lipophilicity [66], which is postulated to prolong their intraluminal airway deposition [25] and dissolution time [22]. However, the advantage gained by longer airway immunosuppression 
Fig. 2 Key milestones in the development of budesonide. $C O P D$ chronic obstructive pulmonary disease, $D P I$ dry powder inhaler, $p M D I$ pressurised metered-dose inhaler

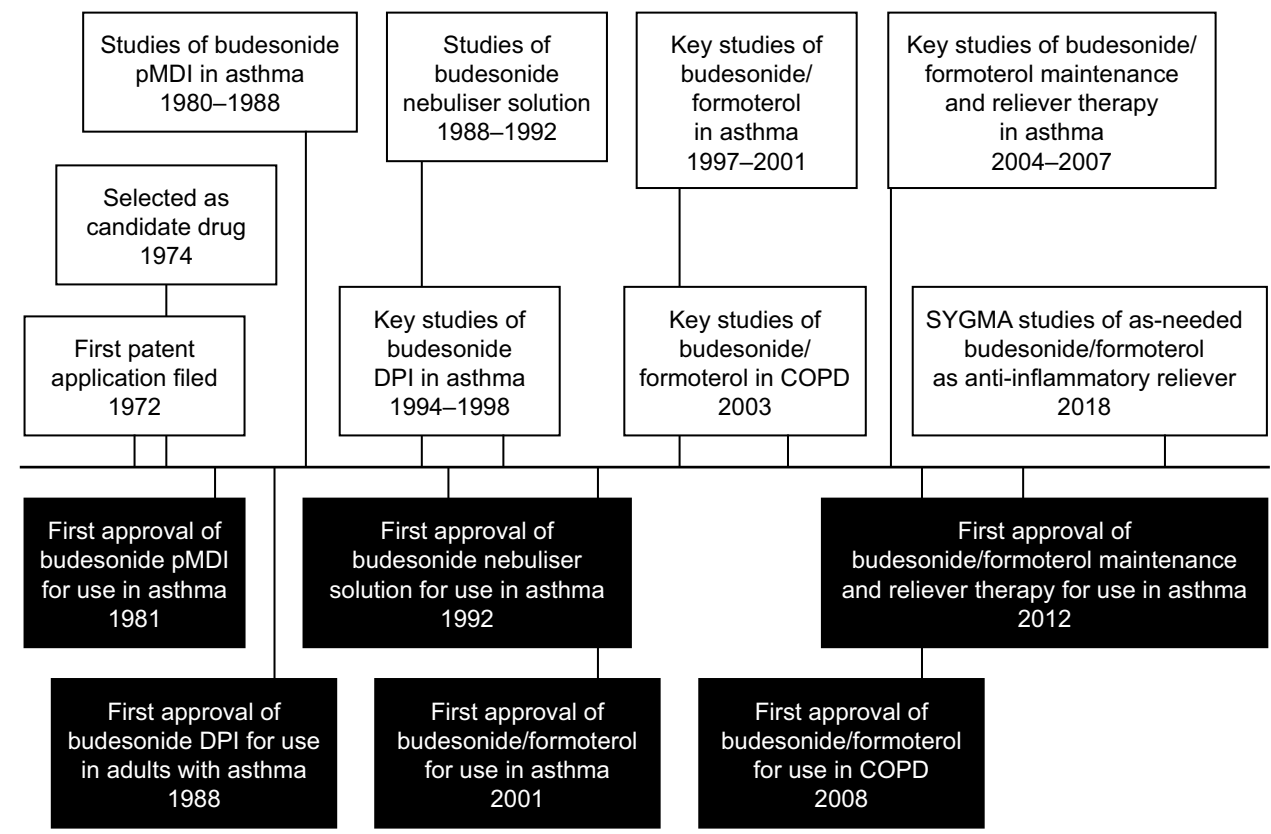

introduces the potential for increased local adverse effects, which may also happen at a systemic level, as these agents have a long terminal half-life [16, 22]. As briefly reviewed in this section, budesonide's pharmacokinetic/pharmacodynamic properties make for a better balance between efficacy and safety than many of these newer ICS.

Budesonide is relatively less lipophilic, and hence more water soluble, than most other ICS [25, 67], which results in a shorter dissolution time in human bronchial fluid in vitro compared with other ICS (Table 1) $[67,71]$. This allows it to enter the lung tissues quickly, minimising removal from the airways by mucociliary clearance or phagocytosis [67, $72,73]$. In contrast, very low water solubility with, for example, FF, MF and CIC (Table 1) prolongs the intraluminal dissolution time of these ICS and can extend their local anti-inflammatory efficacy [22]. However, such increased pulmonary residence time may also enhance the duration of the local immunosuppressive action of ICS in the airways/ lung. This may be particularly important in the presence of impaired mucociliary clearance and altered lung microbiome in COPD, potentially increasing the risk of pneumonia [74, 75].

Absolute bioavailability, the drug taken up directly from airways/lung plus the swallowed and intestinally absorbed fraction bypassing the liver unmetabolised [22], is indicative of the potential for systemic distribution. Budesonide's absolute bioavailability is lower than that of BDP, and although it is greater than that of FLU, FP and MF (Table 2), several factors help to reduce the extent and duration of its systemic tissue absorption and its distribution. Firstly, it is cleared rapidly following systemic absorption-with a broadly similar clearance rate to FLU, FP and MF (Table 2) [22].
Secondly, ICS with higher lipophilicity have prolonged systemic elimination; the relatively lower lipophilicity of budesonide is thought to explain its shorter elimination half-life than that of FP, FF and MF (Table 1). Thirdly, in the systemic circulation, higher lipophilicity also results in a higher volume of distribution $\left(V_{\mathrm{d}}\right)$ which, along with prolonged systemic elimination, potentially results in drug accumulation in other body tissues and risk of more prolonged systemic exposure during repeated dosing (Fig. 3) [22, 37, 66, 76]. Budesonide's moderate lipophilicity is associated with a smaller $V_{\mathrm{d}}$ than, for example, CIC, FP, MF and FF (Table 2; Fig. 3) and therefore with shorter systemic exposure, contributing to a low risk of adverse events [15, 37, 39, 66].

\subsection{Intracellular Pharmacodynamic Properties}

After absorption into airway tissues, a considerable fraction of budesonide undergoes reversible intracellular esterification to produce highly lipophilic fatty acids in an inactive depot form (mainly budesonide-21-oleate) [77]. This occurs via lipid conjugation of budesonide's free hydroxyl group at carbon 21 (Fig. 4) [78]. Although lipid conjugation has also been observed with other ICS with a free hydroxyl group $[22,79]$, it is best documented for budesonide. As intracellular levels of free budesonide fall over time, these conjugates are hydrolysed by lipases, releasing more of the active drug to interact with the GCR [80]. It can be proposed that the esterification process therefore acts as a 'sustained-release' mechanism that prolongs lung residence time at the intracellular target level [80, 81]. This explains budesonide's high and extended local efficacy for a non-halogenated ICS with only moderate lipophilicity, in contrast with the more 
Table 1 Properties of ICS

\begin{tabular}{|c|c|c|c|c|c|c|}
\hline Corticosteroid & $\begin{array}{l}\text { Lipophilicity } \\
(\log P)^{\mathrm{a}}[25]\end{array}$ & $\begin{array}{l}\text { Water solubility } \\
(\mu \mathrm{g} / \mathrm{mL})[25,67]\end{array}$ & $\begin{array}{l}\text { Dissolution time (human } \\
\text { bronchial fluid in vitro) } \\
{[67]}\end{array}$ & Half-life (h) [22] & $\begin{array}{l}\text { GCR binding } \\
\text { affinity }^{\mathrm{c}}[22, \\
25]\end{array}$ & $\begin{array}{l}\text { Selectivity for the } \\
\text { GCR vs the PR } \\
{[68]}\end{array}$ \\
\hline $\begin{array}{c}\text { Beclometasone } \\
\text { dipropionate }\end{array}$ & 4.59 & 0.13 & $>5 \mathrm{~h}$ & 0.1 & 53 & NA \\
\hline $\begin{array}{l}\text { 17-Beclometasone } \\
\text { monopropionate }^{\mathrm{d}}\end{array}$ & 3.27 & 15.5 & ND & 2.7 & 1345 & 9.3 \\
\hline Budesonide & 2.32 & 16 & $6 \mathrm{~min}$ & 2.8 & 935 & 44 \\
\hline Fluticasone propionate & 3.89 & 0.14 & $>8 \mathrm{~h}$ & $>14$ & $1775-1800$ & 11.8 \\
\hline Fluticasone furoate [69] & 4.17 & $<0.1$ & NA & $17-24[70]$ & $2989 \pm 135$ & NA \\
\hline Mometasone furoate & 4.73 & $<0.1$ & ND & 4.5 & $2100-2200$ & 1.1 \\
\hline Ciclesonide & 3.2 & $<0.1$ & ND & 0.4 & 12 & NA \\
\hline $\begin{array}{l}\text { Desisobutyryl- } \\
\text { ciclesonide }^{\mathrm{e}}\end{array}$ & 3.0 & 7 & ND & $3.6-5.1$ & 1200 & NA \\
\hline Flunisolide [69] & 1.36 & 140 & NA & 1.6 & 177 & NA \\
\hline
\end{tabular}

$G C R$ glucocorticoid receptor, ICS inhaled corticosteroids, $N A$ not available in current literature, $N D$ not determined, $P R$ progesterone receptor

${ }^{a} \log p$ values are defined as the $\log _{10}$ of the octanol/water partition coefficient

${ }^{\mathrm{b}}$ Water solubility at $37^{\circ} \mathrm{C}$

${ }^{c}$ Relative receptor affinity with reference to a receptor affinity of dexamethasone of 100

${ }^{\mathrm{d}}$ Active metabolite of beclometasone dipropionate

${ }^{\mathrm{e}}$ Active metabolite of ciclesonide

Table 2 Pharmacokinetic properties of ICS

\begin{tabular}{|c|c|c|c|c|}
\hline Corticosteroid & $\begin{array}{l}\text { Absolute bioavailability }{ }^{\mathrm{a}} \\
(\%)[25]\end{array}$ & $\begin{array}{l}\text { Clearance }(\mathrm{L} / \mathrm{h})[22, \\
25]\end{array}$ & $\begin{array}{l}\text { Volume of distribution (L) } \\
{[22,25]}\end{array}$ & $\begin{array}{l}\text { Protein- } \\
\text { binding }(\%) \\
{[22,25]}\end{array}$ \\
\hline Beclometasone dipropionate & $82 *$ & $120-230$ & 20 & $87-96$ \\
\hline 17-Beclometasone monopropionate ${ }^{\mathrm{b}}$ & ND & $120^{\dagger}$ & $424^{\dagger}$ & NA \\
\hline Budesonide & $39^{\#}$ & 84 & $180-183$ & $88-91$ \\
\hline Fluticasone propionate & $16^{\#}$ & 69 & 318 & $90-99$ \\
\hline Fluticasone furoate [69] & $15^{\#}$ & 65 & 608 & 99 \\
\hline Mometasone furoate & $11^{\#}$ & 54 & 332 & $98-99$ \\
\hline Ciclesonide & $63^{*}$ & $152-228$ & $207-396$ & 99 \\
\hline Desisobutyryl-ciclesonide $^{c}$ & ND & $396^{\dagger}$ & $1190^{\dagger}$ & 99 \\
\hline Flunisolide [69] & $70^{*}$ & 58 & 96 & $61-80$ \\
\hline
\end{tabular}

ICS inhaled corticosteroids, $N A$ not available in current literature, $M D I$ metered-dose inhaler, $N D$ not determined

*Hydrofluoroalkane propellant MDI

${ }^{\#}$ Dry-powder inhaler

${ }^{\dagger}$ Apparent maximum approximation based on complete conversion of the parent compound

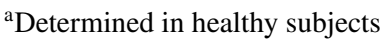

${ }^{\mathrm{b}}$ Active metabolite of beclometasone dipropionate

${ }^{\mathrm{c}}$ Active metabolite of ciclesonide

lipophilic ICS that are proposed to have extended airway residence due to their prolonged intraluminal dissolution time [77, 81]. Because the esterification process is driven by high budesonide concentrations, far fewer budesonide esters are formed within peripheral cells $[78,81,82]$. The ability of budesonide to undergo a reversible partial esterification preferentially within airway cells is thought to create the unique ability to have a higher lipophilicity at the target tissue than when circulating in the body [78, 81, 83].

The binding affinity of ICS for the target GCR appears to be related to their lipophilicity, with budesonide having a considerably lower affinity than more lipophilic ICS such 
Relative Blood/Tissue Partition at Steady-State

Larger volume of distribution

Higher lipophilicity (e.g. FF/FP/MF)

Systemic tissue $\gg>$ Blood

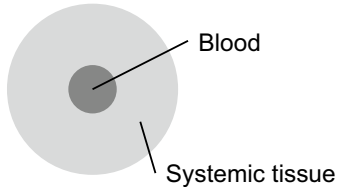

Smaller volume of distribution

Lower lipophilicity (e.g. FLU/BUD)

Blood >>> Systemic tissue

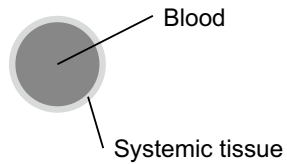

Fig. 3 Schematic diagram showing the difference in partitioning of high and low lipophilicity drugs between the hydrophilic (water soluble) blood compartment and the lipophilic (fat soluble) systemic tissue compartment and their total volume of distribution. BUD budesonide, $F F$ fluticasone furoate, $F P$ fluticasone propionate, $F L U$ flunisolide, $M F$ mometasone furoate

as MF, FP or FF (Table 1) [22]. However, a highly lipophilic inhaled ICS extends local tissue binding and GCR triggering [71], but when further distributed into the systemic circulation it may worsen the risk:benefit ratio due to its greater and longer systemic exposure [22].

Although budesonide has a lower GCR binding affinity, it offers the advantage of greater selectivity for the GCR versus the PR as compared with some other ICS (at least according to one study; Table 1); differences in GCR selectivity may be inversely related to lipophilicity [68]. This greater GCR versus PR selectivity may help avoid further systemic adverse effects, particularly at higher doses, when it is thought ICS may then also bind to the PR, which has a similar binding domain to the GCR [68].

\subsection{Pharmacodynamic Rationale for ICS/ Long-Acting $\boldsymbol{\beta}_{2}$-Agonist (LABA) Combination Therapy}

Numerous potential intracellular mechanisms of synergistic interaction between corticosteroids and $\beta_{2}$-agonists have been identified [85]. Synergy has proved difficult to confirm in vivo, although additive effects have been demonstrated [41, 86-90], providing a rationale for the combination of

ICS and LABA for the treatment for asthma and COPD [85, 87, 91, 92]. Indeed, corticosteroids bind to a positive GRE and increase the gene transcription of $\beta_{2}$-adrenoceptors in human lung tissue in vitro [93], thus increasing the expression of $\beta_{2}$-receptors and protecting against their downregulation and G-protein adenylyl cyclase uncoupling after long-term administration of $\beta_{2}$-agonists [94-97]. There is also some evidence of activation of the GCR by $\beta_{2}$-agonists which augments translocation of the bound GCR into the nucleus and may mediate the anti-inflammatory effect of ICS in vitro and in vivo $[98,99]$. In addition, there is also evidence of 'coincident pharmacology' for ICS and LABA, resulting from a higher co-deposition on the same cells with the combined inhaler $[85,100]$. This is supported by evidence of augmented ICS-induced GCR nuclear translocation in airway cells when an ICS is administered in combination with a LABA [98].

\section{Budesonide Studies in Asthma}

An abundance of data exists concerning budesonide treatment in patients with all severities of asthma. Budesonide $600 \mu \mathrm{g}$ twice daily (bid) was compared with terbutaline $375 \mu \mathrm{g}$ bid over 2 years in patients in whom asthma had appeared within the previous year [56]. Forced expiratory volume in one second $\left(\mathrm{FEV}_{1}\right)$, morning and evening PEF and asthma symptoms all improved with budesonide versus terbutaline, and the budesonide group also needed less 'rescue' terbutaline. These results supported early use of budesonide in newly detected asthma. A 1-year follow-up study to investigate the effect of reducing or discontinuing the steroid dose [57] from 1200 to $400 \mu \mathrm{g}$ found that, compared with placebo, the lower budesonide dose maintained reduced bronchial hyperresponsiveness to histamine in $74 \%$ versus $33 \%$ of patients, with significant differences also seen in pulmonary function. A 2-year study with budesonide $400 \mu \mathrm{g}$ bid and a 12-month study of early intervention with low-dose (200 $\mu \mathrm{g}$ bid) budesonide also supported early treatment with an ICS $[60,101]$. Low maintenance doses of budesonide 100-200 $\mu \mathrm{g}$ bid have also proved effective in reducing severe
Fig. 4 Structural formulas of budesonide and budesonide21-fatty acid esters [81, 84]. Reproduced with permission from Tunek et al. [84]

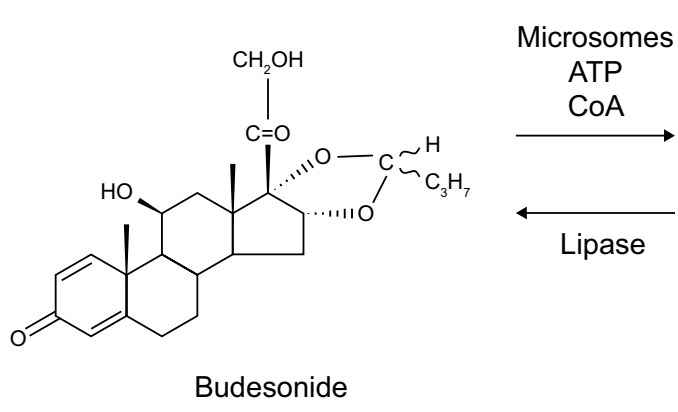


exacerbations and improving asthma control in patients with mild asthma [102].

The dose-dependent nature of budesonide's clinical efficacy was elucidated in a 12-week study in patients with moderate-to-severe asthma published in 1998 [63]. Budesonide was administered twice daily at a total dose of 200 , 400, 800 or $1600 \mu \mathrm{g}$. The effects on PEF and $\mathrm{FEV}_{1}$ were significantly greater with the $1600-\mu$ g dose than with the $200-\mu \mathrm{g}$ dose, although not for the other doses studied. Flexible dosing with budesonide has also been investigated in patients with mild asthma [103]. Subjects were randomised to budesonide $200 \mu \mathrm{g}$ bid, BDP $250 \mu \mathrm{g}$ bid or non-steroidal treatment for 2 years, with the ICS dose adjusted according to asthma severity and treatment response. The patients receiving ICS had a more rapid and marked increase in $\mathrm{FEV}_{1}$ and morning PEF compared with non-steroidal treatment, with the changes inversely correlated to mean ICS dose $(p<0.001)$.

The efficacy of budesonide in children has been investigated in several studies, notably the long-term Steroid Treatment As Regular Therapy (START) and the Childhood Asthma Management Program (CAMP) trials [104, 105]. The START study included 7241 patients, over a quarter of whom were children younger than 11 years [105]. Daily doses of budesonide $400 \mu \mathrm{g}$, or $200 \mu \mathrm{g}$ for children, were compared with placebo. Budesonide significantly reduced the risk of a first severe asthma-related event by $44 \%$ (hazard ratio $0.56,95 \% \mathrm{CI} 0.45-0.71 ; p<0.0001)$. There were also significant increases in pre- and post-bronchodilator $\mathrm{FEV}_{1}$ and symptom-free days compared with placebo, supporting the use of long-term treatment with once-daily, low-dose budesonide in patients with recent-onset mild asthma. The CAMP study compared the efficacy of budesonide $200 \mu \mathrm{g}$ bid and nedocromil sodium $8 \mathrm{mg}$ bid with placebo for 4-6 years in 1041 children with mild-to-moderate asthma [104]. Budesonide treatment did not significantly increase post-bronchodilator $\mathrm{FEV}_{1}$, although there were significant improvements in asthma symptoms, use of rescue medication, number of episode-free days and airway responsiveness to methacholine compared with placebo $(p \leq 0.01)$. Efficacy has also been shown with nebulised budesonide (Pulmicort ${ }^{\circledR}$ Respules ${ }^{\circledR}$ ) in children with steroid-dependent, persistent asthma [65].

\section{Budesonide Studies in COPD}

In the European Respiratory Society study on COPD (EUROSCOP), twice-daily budesonide $400 \mu \mathrm{g}$ administered via DPI was compared with placebo over 3 years in patients with mild COPD who continued smoking [106]. The primary endpoint, change in post-bronchodilator $\mathrm{FEV}_{1}$, improved with budesonide treatment in the first 6 months of the study, but the changes from 9 months to the end of treatment were not significantly different. The median decline in $\mathrm{FEV}_{1}$ over 3 years was $140 \mathrm{~mL}$ in the budesonide group and $180 \mathrm{~mL}$ with placebo $(p=0.05)$; or $4.3 \%$ and $5.3 \%$ of the predicted values, respectively ( $p=0.04$ ).

Nebulised budesonide has also been studied in COPD patients. In one study, budesonide $2 \mathrm{mg}$ every $6 \mathrm{~h}$ for $72 \mathrm{~h}$ delivered by Pulmicort ${ }^{\circledR}$ Respules ${ }^{\circledR}$ was compared with oral prednisolone $30 \mathrm{mg}$ every $12 \mathrm{~h}$ and placebo for the treatment of acute COPD exacerbations. Improvements in postbronchodilator $\mathrm{FEV}_{1}$ over $72 \mathrm{~h}$ were greater in both treatment groups versus placebo (budesonide versus placebo, $0.10 \mathrm{~L}$ [0.02-0.18]; prednisolone versus placebo, $0.16 \mathrm{~L}$ [0.08-0.24]), suggesting that nebulised budesonide could have value in treating acute COPD exacerbations [107].

\section{Budesonide/Formoterol Studies in Asthma}

Treatment with budesonide in combination with the fastacting LABA, formoterol, has been extensively investigated in patients with asthma. In the FACET (Formoterol and Corticosteroids Establishing Therapy) study, the addition of formoterol to budesonide via separate inhalers significantly reduced mild and severe exacerbations compared with budesonide alone $(p<0.01)$. Mean symptom scores and rescue medication use were also significantly improved $(p<0.001)$ [90]. Similar results were obtained when patients received twice-daily maintenance therapy with budesonide/formoterol from a single inhaler [108]. A large real-world study using a retrospective matched cohort population database analysis showed lower rates of exacerbation and healthcare utilisation with the budesonide/formoterol combination than with salmeterol/fluticasone in asthma [109]. This combination treatment was first approved for use in asthma in 2001 and is currently available in a choice of pMDI or DPI devices. Budesonide/formoterol by DPI is also potentially suitable for once-daily dosing in patients with asthma, due to the long duration of action of both mono-components $[81,110]$.

\section{Budesonide/Formoterol Studies in COPD}

The budesonide/formoterol combination has also been investigated in patients with COPD. In two large, 12-month studies, twice-daily treatment with budesonide/formoterol $320 / 9 \mu \mathrm{g}^{1}$ delivered via DPI reduced the mean number of

\footnotetext{
${ }^{1}$ Delivered dose, corresponds to a budesonide/formoterol metered dose of $400 / 12 \mu \mathrm{g}$.
} 
severe exacerbations versus all comparators $(p<0.05$ versus formoterol) $[111,112]$, leading to the approval of this treatment in 2008 (not via DPI in the USA) for patients with COPD and a history of repeated exacerbations. In the 12-month SUN study [113], the higher strength budesonide/ formoterol pMDI formulation (160/4.5 $\mu^{2}$ bid) improved pre-dose $\mathrm{FEV}_{1}$ and prolonged time to first COPD exacerbation versus formoterol ( $p=0.008$ and $p=0.026$, respectively). Both budesonide/formoterol formulations (160/4.5 and $80 / 4.5 \mu \mathrm{g}^{3}$ bid) reduced the overall number of exacerbations per patient-treatment year versus formoterol $(25 \%$ and $29 \%$, respectively; $p \leq 0.004$ ). In the 6-month SHINE study [114], greater improvements in pre-dose $\mathrm{FEV}_{1}$ and 1-h post-dose $\mathrm{FEV}_{1}$ were observed with budesonide/formoterol $160 / 4.5 \mu \mathrm{g}$ bid pMDI versus the primary comparators of formoterol $(p=0.026)$ and budesonide $(p<0.001)$, respectively. The recent RISE study compared budesonide/ formoterol pMDI 320/9 $\mu \mathrm{g}$ bid with formoterol DPI $9 \mu \mathrm{g}$ bid for 6 months in patients with moderate-to-very-severe COPD and a history of exacerbations [115]. Both the annual rate of moderate and severe exacerbations and the time to first exacerbation were significantly reduced with budesonide/formoterol treatment versus formoterol alone. The pMDI formulation of budesonide/formoterol 320/9 $\mu \mathrm{g}$ was approved by the US FDA for COPD in 2009 and for reduction of COPD exacerbations in 2017.

A number of other ICS/LABA DPI combination treatments have been approved for use in patients with COPD, but direct comparisons between these treatments are limited. In the retrospective, observational PATHOS study in matched patients with COPD, budesonide/formoterol was shown to significantly reduce the exacerbation rate versus salmeterol/FP (0.80 vs 1.09 exacerbations per patient-year) [116]. All other adverse healthcare outcomes were also significantly reduced with budesonide/formoterol. Similar results had been observed in another matched cohort population-based study in patients with COPD [117].

Due to the fast onset of bronchodilation with formoterol [118], budesonide/formoterol combinations can also be of benefit in patients with severe COPD who experience their worst symptoms in the early morning when lung function is at its lowest ebb, due to diurnal variation. In one study, short-term treatment with budesonide/formoterol 320/9 $\mu \mathrm{g}$ bid resulted in a significantly greater improvement in ability to perform morning activities $(p<0.05)$ than with salmeterol/fluticasone propionate $50 / 500 \mu \mathrm{g}$ bid [119]. The CLIMB study showed that 12 weeks' treatment with the same dose of

\footnotetext{
${ }^{2}$ Delivered dose, corresponds to a budesonide/formoterol metered dose of $200 / 6 \mu \mathrm{g}$.

${ }^{3}$ Delivered dose, corresponds to a budesonide/formoterol metered dose of $100 / 6 \mu \mathrm{g}$.
}

budesonide/formoterol and the addition of tiotropium $18 \mu \mathrm{g}$ once daily resulted in rapid and sustained improvements in morning lung function, symptoms, reliever use and activities and a $62 \%$ reduction in exacerbations versus tiotropium alone [120]. Interestingly, budesonide has been found to enhance the fast onset of action of formoterol in patients with stable COPD, possibly due to non-genomic actions that can occur within a few minutes [121].

\section{Budesonide/Formoterol as Both Maintenance and Reliever Therapy in Asthma}

Formoterol has a fast onset of bronchodilator effect similar to salbutamol [118], and although the bronchodilator effects last much longer than salbutamol, systemic effects are equally short-lived [122]. This enables more flexibility of dosing with a budesonide/formoterol combination than other ICS/LABA combinations where the LABA has a slower onset of effect and more prolonged systemic effects. The high water solubility and moderate lipophilicity of budesonide leads to dissolution in airway lining fluid within minutes, and subsequent rapid absorption into airway/lung tissue [22, 123]. One study has shown that, within $2 \mathrm{~h}$ of administration, a bolus dose of inhaled budesonide reverses subsensitivity to adenosine monophosphate bronchoprotection and associated down-regulation of lymphocyte $\beta_{2}$-adrenoreceptors produced by regular formoterol treatment in patients with asthma [95]. The results from this study support the use of additional bolus doses of inhaled corticosteroids in conjunction with $\beta_{2}$-agonists for the treatment of acute episodes of bronchoconstriction.

The use of budesonide/formoterol as an as-needed reliever with anti-inflammatory properties in addition to maintenance therapy provides an alternative to higher maintenance doses of ICS alone, and enables earlier, symptomled intervention with ICS when patients experience worsening symptoms, potentially preventing the development of exacerbations (Fig. 5) [124, 125]. Regulatory approval outside of the US has been given for the budesonide/formoterol combination in a single DPI to be used in this way. This is a valuable additional approach to asthma management that fits in with how most patients actually behave, increasing reliever use when symptoms worsen [126, 127], whilst giving clinicians the reassurance that their patients will also receive an anti-inflammatory dose of budesonide with every dose of reliever.

To evaluate the specific contribution of as-needed budesonide/formoterol as a reliever against a background of maintenance therapy, the efficacy of three reliever strategies was investigated [128]. Patients with moderate to severe persistent asthma remaining symptomatic on budesonide/ 


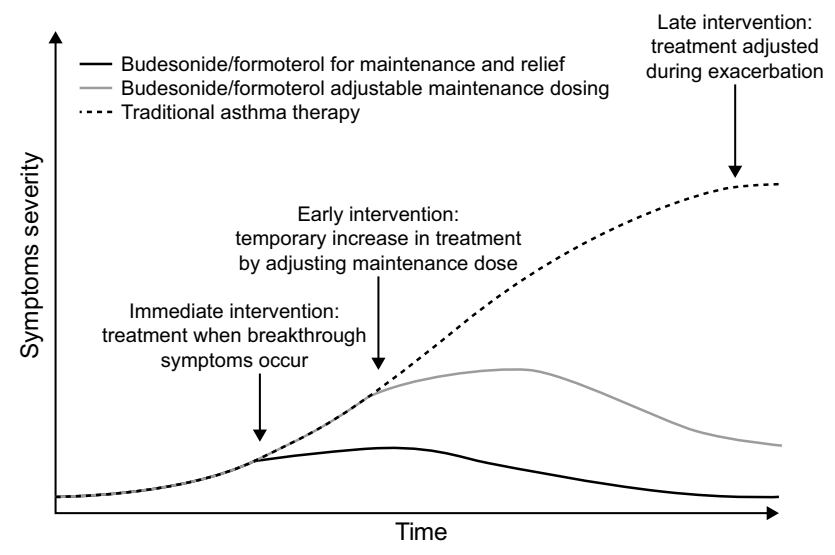

Fig. 5 Illustration of outcomes with different asthma treatment regimens in response to worsening symptoms [124]. Reproduced with permission from Ankerst [124]

formoterol maintenance therapy received terbutaline, formoterol or budesonide/formoterol as reliever medications for 12 months. Interestingly, both mono-components were shown to be important when given as needed in addition to budesonide/formoterol maintenance therapy, with formoterol reducing severe exacerbations to a greater extent than terbutaline. However, greater reductions in severe exacerbations were observed with budesonide/formoterol as both maintenance and reliever compared with formoterol as an as-needed reliever therapy on top of budesonide/formoterol maintenance treatment [128].

\section{Safety}

Inhaled corticosteroids have been associated with a risk of certain adverse events, such as pneumonia, oropharyngeal Candida infection and lower respiratory tract infections such as tuberculosis and non-tuberculous mycobacterioses. This is potentially due to immunosuppressive effects resulting from the relatively high local concentrations of these medications in the airways/lung [14, 129-132]. Systemic adverse effects can include reductions in bone mineral density (BMD), adrenal suppression, cataracts, and glaucoma [17, 103], as well as skin bruising [133]. A number of clinical trials and long-term studies have assessed the safety profile of budesonide and found the risk:benefit ratio to be favourable, both in asthma and COPD [39, 106, 134].

\subsection{Safety in Asthma}

In an analysis of asthmatic patient data from The Health Improvement Network database, budesonide use was associated with a small increase (odds ratio (OR) 1.20, 95\% CI $1.06-1.35 ; p=0.003$ ) in the risk of pneumonia or a lower respiratory tract infection (LRTI), while the risk of these events was much greater with FP (OR 1.64, 95\% CI $1.50-1.79 ; p<0.001)$ [129]. In the START study $(n=7241)$ of early intervention in mild asthma, the frequency of infections was similar between budesonide and placebo (38.5\% vs $38.3 \%)$ [39, 105], as was the incidence of tuberculosis $(0.1 \%$ for placebo and $0.3 \%$ for budesonide) $[39,134]$.

The association of OCS with the development of osteoporosis is well documented, but the effect of ICS on bone metabolism and bone density is less clear [103]. In a longterm study of inhaled budesonide in children with asthma, there were no adverse effects on BMD, total bone calcium, total body bone mineral capacity or body composition after 3-6 years of treatment. The mean daily budesonide dose was $504 \mu \mathrm{g}$, and there was no correlation between duration of treatment and bone density parameters [135]. When changes in BMD were compared between ICS and non-ICS treatments over 2 years in adults with mild asthma, no significant differences were observed between budesonide, BDP or a non-steroid reference treatment [103]. There was a correlation between ICS dose and a reduction in BMD at the lumbar spine over the 2-year study, possibly due to a direct effect on bone or to an indirect effect related to asthma severity, but overall the data suggest that low to moderate doses of ICS have little effect on BMD over 2 years. A 1-year, open-label study in 59 adult patients with moderate-to-severe asthma reported no significant difference between high-dose budesonide and high-dose FP in BMD, and no significant decline in BMD overall [136].

The systemic potency of ICS can be measured by their effects on the hypothalamic-pituitary-adrenal (HPA) axis, and a number of long-term trials have studied this [39]. HPA axis function was one of the safety endpoints in a 52-week, open-label study of budesonide (100-800 $\mu \mathrm{g}$ bid) in adults and children [137]. There was no evidence of any suppression in function, as both basal and stimulated plasma cortisol levels were maintained throughout the study. These results were reflected in two further studies in children on longterm budesonide treatment, with one study even showing improvements in adrenal function with budesonide over 6-12 months [138, 139]. Budesonide has also been shown to have a minimal effect on serum cortisol levels and bone turnover in comparison with microgram-equivalent doses of FP [17, 140-143].

A long-term study of children with mild-to-moderate asthma by the CAMP Research Group assessed the effect of ICS on lung function and growth over 4-6 years [104]. Children receiving budesonide $200 \mu \mathrm{g}$ bid showed no significant difference in lung function versus placebo at 4 years, as measured by change in post-bronchodilator $\mathrm{FEV}_{1}$, despite an improvement at 1 year. The budesonide group showed a small, transient reduction in growth velocity versus placebo, primarily evident within the first year. However, growth 
velocity was similar by the end of the treatment period, and changes in bone density and end-of-treatment bone age, projected final height and Tanner stage were all similar to placebo. The growth velocity findings were supported by an 18-month study of continuous low-dose budesonide or continuous budesonide for 6 months then as needed [144]. A small initial decline in growth velocity with both budesonide treatment regimens normalised by the end of the trial, with budesonide as-needed associated with catch-up growth. No long-term adverse effects on growth velocity or weight gain were seen in further studies in asthmatic children with daily budesonide doses of up to $400 \mu \mathrm{g}$ [59]. While a metaanalysis in children with mild-to-moderate persistent asthma found greater reductions in 1-year mean linear growth velocity with budesonide than with several other ICS (CIC, FLU, FP and MF) using indirect comparison methods, the differences were small $(-0.59$ versus -0.08 to $-0.47 \mathrm{~cm} /$ year $)$ and their clinical relevance was not clear [145].

Other systemic adverse effects linked to the long-term use of high-dose ICS include cataracts, glaucoma, and ocular hypertension [17]. However, two studies in children with asthma found no increase in occurrence of posterior subcapsular cataracts versus controls after up to 6 years' treatment with budesonide [104, 146].

Data from large-scale retrospective studies have shown that treatment with anti-asthmatic medications can increase the risk of pregnancy complications and low infant birth weight [147, 148], although budesonide-specific data have not shown a significant increase in congenital malformations $[39,149]$. A study in pregnant mice showed less transplacental transfer of free budesonide than of free FP [150]. This appeared to depend on the lower lipophilicity of budesonide and the fact that, as a substrate for P-glycoprotein, budesonide can be transported out of the placenta and brain.

\subsection{Safety in COPD}

An increased incidence of pneumonia in COPD patients receiving ICS treatment has been observed in several studies, although there are indications of intra-class differences in risk [75, 151, 152]. Recent studies in human bronchial epithelial cells have shown that treatment with budesonide results in significantly higher expression of specific immune defence genes, and greater airway epithelial barrier protection against cigarette smoking and viral infection, than treatment with FP [31, 75, 153]. Due to its greater lipophilicity and tenfold higher immunosuppressant potency, the prolonged residency time of FP in the airway epithelial lining fluid compared with budesonide may result in an increased duration of local immunosuppression and impaired pathogen clearance from the airways [14, 75, 154]. Additionally, very recent work has demonstrated a differential response to budesonide compared with FP in blood-derived macrophages in smokers and ex-smokers with COPD [155]. Budesonide counteracted reductions in bacterial recognition receptors on monocyte-derived macrophages by both nontypeable Haemophilus influenzae and Streptococcus pneumoniae, whereas FP only counteracted some of the reductions by $S$. pneumoniae. These differences may provide a greater understanding of mechanisms by which patients taking fluticasone-based preparations for COPD tend to be more susceptible to pneumonia [14]. The European Medicine Association's Pharmacovigilance Risk Assessment Committee reviewed the known risk of pneumonia with ICS in 2016 and concluded that, although COPD patients treated with ICS are at increased risk of pneumonia, the benefits of ICS continue to outweigh their risks [156]. In a population-based cohort study of patients with COPD, budesonide was associated with a comparatively much lower risk of pneumonia ( $17 \%$ increased risk with no dose-response effect) than FP (dose-dependent increase, with the 1000- $\mu \mathrm{g}$ dose associated with a $122 \%$ increase in risk) or other ICS (primarily BDP) [74]. A meta-analysis of 43 studies made indirect comparisons of budesonide and fluticasone monotherapy and found a higher risk of any pneumonia event with fluticasone than with budesonide (OR 1.86, 95\% CI 1.04-3.34), although between-group differences were not significant for non-fatal serious adverse pneumonia events or mortality [157]. The authors cautioned interpretation of these results due to the quality of evidence and the indirect nature of the comparison [157]. In the FULFIL study, the rate of pneumonia in patients with COPD was lower with twice-daily budesonide/formoterol than with a once-daily triple therapy of fluticasone furoate/umeclidinium/vilanterol (FF/UMEC/VI) [158]. The incidence of pneumonia, a prespecified adverse event of special interest, over 24 weeks in the intention-to-treat population was $2.2 \%$ with FF/UMEC/ VI versus $0.8 \%$ with budesonide/formoterol. Additionally, in the PATHOS study, budesonide/formoterol was associated with a significantly lower rate of pneumonia and hospital admission for pneumonia (both $p<0.001$ ) than salmeterol/ FP in matched cohorts of patients with COPD [14]. The risk of pneumonia was not associated with the dose of ICS received for either treatment. The 6-month KRONOS trial showed similar rates of confirmed pneumonia (2\%) for both budesonide/glycopyrrolate/formoterol and glycopyrrolate/ formoterol [159].

A meta-analysis of seven large clinical studies concluded that treatment with budesonide for 12 months does not increase the risk of pneumonia in patients with COPD as compared with control (formoterol or placebo) [160]. A subsequent meta-analysis that included an eighth large trial found that the incidence of pneumonia increased with increasing severity of airflow limitation, both for patients who received budesonide and those on non-ICS controls [161]. However, although this further trial showed a 
significantly increased pneumonia incidence with budesonide/formoterol compared with formoterol alone, when these data were added to the pooled data from the seven trials, no significantly increased risk of pneumonia with budesonide was noted [162]. Although the overall risk for pneumonia increased with COPD severity, there was no difference in pneumonia risk with budesonide treatment in any Global Initiative for Chronic Obstructive Lung Disease (GOLD) severity group. In the RISE study, the incidence of protocol-defined pneumonia or LRTI adverse events was numerically lower with budesonide/formoterol (pneumonia, $0.5 \%$; LRTI, $1.5 \%$ ) than with formoterol alone (pneumonia, $1.0 \%$; LRTI, 3.3\%) [115]. No patients in the budesonide/formoterol group experienced pneumonia as a serious adverse event, compared with $0.8 \%$ of patients in the formoterol group. A pooled analysis of 11 interventional studies, which included $>10,000$ patients, compared the difference in pneumonia risk between inhaled budesonide-containing and non-budesonide-containing treatments [163]. The risk of pneumonia treatment-emergent adverse events (TEAEs) or serious adverse events (TESAEs) was not significantly increased with budesonide-containing compared with nonbudesonide-containing treatments (pooled HR 1.13 and 1.15 , respectively). The annual incidence rates with budesonide- and non-budesonide-containing products were similar (5.2\% vs $4.6 \%$, respectively, for TEAEs and $1.9 \%$ vs $1.5 \%$ for TESAEs).

As in asthma, changes in BMD have also been observed in clinical trials in COPD patients. In the 3-year, placebocontrolled EUROSCOP study, budesonide $400 \mu \mathrm{g}$ bid had no significant effect on BMD, apart from a small positive effect on femoral trochanter bone density yearly decline $(0.04 \%$ for budesonide vs $0.38 \%$ for placebo; $p=0.02$ ) [106]. The 12-month SUN trial found small but significant decreases in total lumbar spine and total hip BMD with budesonide/ formoterol 320/9 $\mu \mathrm{g}$ versus formoterol $9 \mu \mathrm{g}$, as seen on dual energy X-ray absorptiometry (DEXA) scans, but the clinical relevance of these findings was unclear [113]. Of note, ophthalmology assessments were also performed in the SUN trial, including intraocular pressure and lenticular opacities. Similar minor increases in these parameters were observed across all treatment groups. Budesonide/formoterol 320/9 $\mu \mathrm{g}$ was associated with a small increase from baseline in posterior subcapsular score compared with budesonide/formoterol $160 / 9 \mu \mathrm{g}(p=0.022)$, but other clinically significant ophthalmological changes were infrequent [113].

\section{The Future Role of ICS in Airways Disease}

Historically, ICS clinical trials have not been selective for specific asthma phenotypes. However, current guidelines acknowledge asthma as a heterogeneous condition, with several phenotypes now recognised. The treatable allergic asthma phenotype is often associated with an eosinophilic airway inflammation endotype. These patients usually respond well to ICS treatment, and treatment guided by sputum eosinophil count is associated with a reduced risk of exacerbations compared with guidelines-based treatment [18]. Existing biomarkers such as blood eosinophil count, levels of nitric oxide in exhaled breath (FeNO) and serum immunoglobulin $\mathrm{E}$, in addition to developments in new biomarkers and tools for personalised medicine, will play an increasing role in asthma management in the future [164].

The use of ICS/LABA combination therapy in patients with asthma is evolving. While it has traditionally been viewed as controller therapy, the potential of using this combination alone as an as-needed reliever in mild asthma has now been investigated in the two SYGMA (SYmbicort Given as needed in Mild Asthma) studies [165, 166]. In SYGMA 1, the severe exacerbation rate was reduced by $64 \%$ with as-needed budesonide/formoterol versus terbutaline (annualised exacerbation rates 0.07 and 0.20 , respectively; rate ratio (RR) 0.36 ), and was not significantly different from that of budesonide maintenance plus as-needed terbutaline as reliever (annualised exacerbation rates 0.07 and 0.09 , respectively; RR 0.83 ). Superiority to terbutaline and equivalence to budesonide maintenance plus terbutaline were also seen in time to first severe exacerbation. Glucocorticoid exposure was substantially lower with as-needed budesonide/formoterol than with budesonide maintenance in both studies: the median metered daily ICS dose was $83 \%$ lower in the budesonide/formoterol group compared with the budesonide maintenance group in SYGMA 1 (57 $\mu \mathrm{g}$ and $340 \mu \mathrm{g}$, respectively) and 75\% lower in SYGMA 2 (66 $\mu \mathrm{g}$ and $267 \mu \mathrm{g}$, respectively). Together, the SYGMA studies showed that as-needed budesonide/formoterol was superior to as-needed short-acting $\beta_{2}$-agonist (SABA) alone for asthma symptom control and exacerbation risk reduction in mild asthma. The 2019 update to the Global Initiative for Asthma (GINA) report now recommends use of as-needed ICS/formoterol for patients on treatment step 1, replacing SABA as first-line reliever for safety reasons, because SABA has no anti-inflammatory effect and may in fact worsen eosinophilic airway inflammation [167].

GINA now proposes that asthma patients move from asneeded ICS/formoterol only as a reliever up to ICS/formoterol as both maintenance therapy and as-needed reliever therapy, providing a treatment continuum across the spectrum of mild to moderate to severe asthma, with inherent flexibility of dosing and symptom control [167]. Hence, patients may intuitively step up and step down according to asthma control in a personalised flexible dosing regimenin other words, use more when needed and less when not (Fig. 6). 
Continuum of treatment with budesonide/formoterol for mild-moderate asthma

\begin{tabular}{l} 
GINA Step 1/2 \\
\begin{tabular}{|l|l|}
\hline BUD/FORM \\
Anti-inflammatory \\
reliever
\end{tabular} \\
\hline $\begin{array}{l}\text { - Use more when you need it and less when you don't } \\
\text { - Personalised intuitive flexible dosing regimen }\end{array}$ \\
- Always ensures concordance between reliever and preventer \\
- Better control and less overall ICS exposure \\
- Puts the patient in command of their own disease \\
- Paintenance
\end{tabular}

Fig. 6 The continuum of treatment with budesonide/formoterol for mild to moderate asthma. BUD budesonide, FORM formoterol, GINA Global Initiative for Asthma, ICS inhaled corticosteroid

Budesonide/formoterol is currently the only ICS/LABA licenced for this type of use, although this was because these components were well suited to each other in terms of their rapid uptake and short latency time, whereas most later ICS/ LABA combinations were aimed instead at a longer duration of action. By always assuring concordance between budesonide and formoterol in this way, patients will automatically receive their ICS whenever they feel the need to take their reliever therapy. This is not the case with fixed-dose administration of combination ICS/LABA plus SABA reliever regimens, where many patients may stop or adhere poorly to their ICS/LABA and over-rely on their SABA reliever $[168,169]$.

As in asthma, ICS have generally only been tested in a broad COPD population. However, high levels of peripheral blood eosinophils have been reported in a significant proportion of patients with COPD [170], and appear to be predictive of clinical benefit from ICS or ICS/LABA. They may, therefore, have utility in determining which patients with COPD should receive ICS as part of their treatment regimen [21, 170, 171].

Some patients with advanced COPD benefit from triple therapy with an ICS/LABA in combination with a long-acting muscarinic antagonist, and this approach is one of the suggested treatment pathways in the latest GOLD guidelines for Group D patients experiencing further exacerbations [21]. The TRIBUTE study showed an overall $15 \%$ reduction in moderate to severe exacerbations and no increase in pneumonia with beclometasone/formoterol/glycopyrronium versus indacaterol/glycopyrronium [172]. The IMPACT study showed $15 \%$ and $25 \%$ reductions in exacerbations with fluticasone furoate/umeclidinium/vilanterol compared with fluticasone furoate/vilanterol and umeclidinium/vilanterol, respectively. There was a 53\% higher risk of pneumonia with triple therapy versus umeclidinium/vilanterol, and a similarly increased pneumonia risk with fluticasone furoate/ vilanterol [173]. The KRONOS study in moderate to very severe COPD (mostly GOLD group B) showed significantly improved $\mathrm{FEV}_{1}$ area under the concentration-time curve from 0 to $4 \mathrm{~h}\left(\mathrm{AUC}_{0-4}\right)$ with budesonide/glycopyrrolate/ formoterol treatment compared with budesonide/formoterol pMDI and DPI dual combination therapies (both $p<0.0001$ ) [159]. The change from baseline in morning pre-dose trough $\mathrm{FEV}_{1}$ was also significantly improved with triple therapy compared with glycopyrrolate/formoterol $(p=0.0139)$ and budesonide/formoterol pMDI and DPI (both $p<0.0001$ ). Furthermore, there were significant improvements in secondary lung function endpoints compared with budesonide/formoterol, as well as a $52 \%$ reduction in moderate or severe exacerbations compared with glycopyrrolate/formoterol (model-estimated annual RR 0.48, 95\% CI 0.37-0.64; $p<0.0001)$. Pneumonia incidence was low $(<2 \%)$ and similar across treatments [159].

\section{Conclusions}

Many patient-years of clinical experience have been accumulated with budesonide, providing a wealth of evidence of its efficacy and safety profile. Its molecular structure gives budesonide unique pharmacokinetic and pharmacodynamic properties that differentiate it from other ICS. The relatively low lipophilicity and high water solubility of budesonide compared with other ICS allows quicker absorption into lung tissue. The resultant lower volume of distribution, combined with a rapid systemic elimination, is responsible for the low risk of adverse events observed with budesonide in clinical use. The differentiating ability of budesonide to undergo a partial esterification of its free hydroxyl group at carbon 21 increases lipophilicity at the target tissue, prolonging its duration of action at the GCR and extending its airway efficacy and selectivity $[83,174]$.

Among current ICS, budesonide is the most versatile due to its dose-response relationship, including the possibility of administration by nebulisation to infants or the infirm elderly and in an intensive-care setting. Budesonide as a single-drug formulation has proven efficacious as maintenance therapy in both adults and children across a range of asthma severities, with positive results in studies with early intervention, low-dose and flexible-dose regimens. Increased efficacy with the addition of formoterol via a separate inhaler was followed by the introduction of fixed-combination budesonide and formoterol. The fast onset of bronchodilator action with formoterol, combined with the favourable pharmacokinetic properties of budesonide, makes this combination well suited for as-needed use with or without regular maintenance therapy in patients with asthma. This approach ensures treatment with ICS as soon as symptoms worsen. The fast and effective symptom relief provided by budesonide/formoterol is also of benefit to patients with COPD, improving their ability to perform morning activities while the sustained 
effects improve breathlessness throughout the day with twice-daily dosing [119]. In addition, budesonide may be associated with a lower risk of pneumonia than FP or FF in patients with COPD [74].

The recent SYGMA studies showed the superior efficacy of as-needed budesonide/formoterol to as-needed SABA in terms of reducing the risk of exacerbation and improving symptom control in mild asthma. With comparable reductions in exacerbations to budesonide maintenance therapy, but with a lower ICS treatment load and no clinically relevant difference in asthma control, the results support the use of a reliever with anti-inflammatory properties as a flexible and intuitive treatment for mild asthma that accommodates the typical behaviour patterns of patients and improves the benefit:risk ratio of asthma treatment.

Acknowledgements The authors would like to thank Professor Gary P. Anderson, Department of Pharmacology and Therapeutics, The University of Melbourne, and Professor Stephen Rennard, Department of Internal Medicine, University of Nebraska Medical Centre, and Early Clinical Development, BioPharmaceuticals R\&D, AstraZeneca, Cambridge, UK, for invaluable contributions during the early drafting of the manuscript. The authors would also like to thank David Candlish and Stefan Courtney of inScience Communications, Springer Healthcare, Chester, UK, for providing medical writing assistance, funded by AstraZeneca, in accordance with Good Publication Practice (GPP3) guidelines (http://www.ismpp.org/gpp3).

Author Contributions All authors substantially contributed to the planning of the manuscript, critical revision of the draft and final approval of the manuscript.

Data Availability Data sharing not applicable to this article as no datasets were generated or analysed during the current study.

\section{Compliance with Ethical Standards}

Funding This manuscript was supported with funding for medical writing assistance by AstraZeneca, in accordance with Good Publication Practice (GPP3) guidelines (http://www.ismpp.org/gpp3).

Conflict of interest Donald Tashkin has been the recipient of research grant support and fees for speaking and serving as a scientific advisory board member for AstraZeneca, an advisory board member and speaker for Teva, an advisory board member for Innoviva, the recipient of research grant support and an advisory board member for Novartis and a speaker and advisory board member for Sunovion. Brian Lipworth has received support from AstraZeneca for attending ATS 2018 as well as consultancy payments. He has also received payments for speaking, consulting, or advisory boards with Chiesi, Novartis, Sandoz, Sanofi, Teva, Lupin, Genentech, Boehringer Ingelheim, Dr. Reddy's, Cipla, Vectura and Glenmark. Support for unrestricted grants or multicentre trials has been received from AstraZeneca, Teva, Janssen and Chiesi. Equipment and educational support provided by GlaxoSmithKline. Ralph Brattsand is a former employee of Astra and AstraZeneca but today is without economic support from them. He was one of the key inventors of budesonide, and holds stocks with AstraZeneca.

Open Access This article is distributed under the terms of the Creative Commons Attribution-NonCommercial 4.0 International License (http://creativecommons.org/licenses/by-nc/4.0/), which permits any noncommercial use, distribution, and reproduction in any medium, provided you give appropriate credit to the original author(s) and the source, provide a link to the Creative Commons license, and indicate if changes were made.

\section{References}

1. Djukanovic R, Roche WR, Wilson JW, Beasley CR, Twentyman OP, Howarth RH, et al. Mucosal inflammation in asthma. Am Rev Respir Dis. 1990;142(2):434-57.

2. Sutherland ER, Martin RJ. Airway inflammation in chronic obstructive pulmonary disease: comparisons with asthma. J Allergy Clin Immunol. 2003;112(5):819-27.

3. Carryer HM, Koelsche GA, Prickman LE, Maytum CK, Lake $\mathrm{CF}$, Williams HL. The effect of cortisone of bronchial asthma and hay fever occurring in subjects sensitive to ragweed pollen. J Allergy. 1950;21(4):282-7.

4. Hodson ME, Batten JC, Clarke SW, Gregg I. Beclomethasone dipropionate aerosol in asthma. Transfer of steroid-dependent asthmatic patients from oral prednisone to beclomethasone dipropionate aerosol. Am Rev Respir Dis. 1974;110(4):403-8.

5. Brown HM, Storey G, George WH. Beclomethasone dipropionate: a new steroid aerosol for the treatment of allergic asthma. BMJ. 1972;1(5800):585-90.

6. Toogood JH, Baskerville JC, Jennings B, Lefcoe NM, Johansson $\mathrm{SA}$. Influence of dosing frequency and schedule on the response of chronic asthmatics to the aerosol steroid, budesonide. J Allergy Clin Immunol. 1982;70(4):288-98.

7. Renkema TE, Schouten JP, Koeter GH, Postma DS. Effects of long-term treatment with corticosteroids in COPD. Chest. 1996;109(5):1156-62.

8. Crompton G. A brief history of inhaled asthma therapy over the last fifty years. Prim Care Respir J. 2006;15(6):326-31.

9. Gelfand ML. Administration of cortisone by the aerosol method in the treatment of bronchial asthma. N Engl J Med. $1951 ; 245(8): 293-4$

10. Toogood JH, Lefcoe NM. Dexamethasone aerosol for the treatment of "steroid dependent" chronic bronchial asthmatic patients. J Allergy Clin Immunol. 1965;36(4):321-32.

11. Topical corticosteroids. BMJ. 1969;2(5652):297.

12. Brattsand R, Thalen A, Roempke K, Kallstrom L, Gruvstad E. Development of new glucocorticosteroids with a very high ratio between topical and systemic activities. Eur J Respir Dis Suppl. 1982;122:62-73.

13. Thalen A, Brattsand R. Synthesis and anti-inflammatory properties of budesonide, a new non-halogenated glucocorticoid with high local activity. Arzneimittelforschung. 1979;29(11):1687-90.

14. Janson C, Larsson K, Lisspers KH, Stallberg B, Stratelis G, Goike $\mathrm{H}$, et al. Pneumonia and pneumonia related mortality in patients with COPD treated with fixed combinations of inhaled corticosteroid and long acting beta2 agonist: observational matched cohort study (PATHOS). BMJ. 2013;346:f3306.

15. Derendorf H. Pharmacokinetic and pharmacodynamic properties of inhaled corticosteroids in relation to efficacy and safety. Respir Med. 1997;91(Suppl A):22-8.

16. Lipworth B. Systemic safety of fluticasone furoate/vilanterol combination. Thorax. 2013;68(12):1165.

17. Lipworth BJ. Systemic adverse effects of inhaled corticosteroid therapy: a systematic review and meta-analysis. Arch Intern Med. 1999;159(9):941-55.

18. Global Initiative for Asthma (GINA). Global strategy for asthma management and prevention. Updated 2018. http://ginasthma. org/. Accessed 14 June 2019. 
19. The Global Asthma Network. The Global Asthma Report 2018. Auckland: The Global Asthma Network; 2018.

20. Barnes P. NICE technology appraisal guidance [TA138]. Expert written personal statements: Inhaled corticosteroids for asthma in adults and children over twelve years. 2007; https://www.nice. org.uk/guidance/ta138/documents/barnes2. Accessed 14 June 2019.

21. Global Initiative for Chronic Obstructive Lung Disease (GOLD). Global strategy for the diagnosis, management, and prevention of chronic obstructive pulmonary disease. Updated 2019. http:// goldcopd.org/. Accessed 14 June 2019.

22. Derendorf H, Nave R, Drollmann A, Cerasoli F, Wurst W. Relevance of pharmacokinetics and pharmacodynamics of inhaled corticosteroids to asthma. Eur Respir J. 2006;28(5):1042-50.

23. Rhen T, Cidlowski JA. Antiinflammatory action of glucocorticoids-new mechanisms for old drugs. N Engl J Med. 2005;353(16):1711-23.

24. Thornton JW. Evolution of vertebrate steroid receptors from an ancestral estrogen receptor by ligand exploitation and serial genome expansions. Proc Natl Acad Sci USA. 2001;98(10):5671-6.

25. Daley-Yates PT. Inhaled corticosteroids: potency, dose equivalence and therapeutic index. Br J Clin Pharmacol. 2015;80(3):372-80.

26. Horvath $\mathrm{G}$, Wanner A. Inhaled corticosteroids: effects on the airway vasculature in bronchial asthma. Eur Respir J. 2006;27(1):172-87.

27. Buttgereit F, Burmester G-R, Lipworth BJ. Optimised glucocorticoid therapy: the sharpening of an old spear. Lancet. 2005;365(9461):801-3.

28. Barnes PJ. How corticosteroids control inflammation: Quintiles Prize Lecture 2005. Br J Pharmacol. 2006;148(3):245-54.

29. Mostafa MM, Rider CF, Shah S, Traves SL, Gordon PMK, Miller-Larsson A, et al. Glucocorticoid-driven transcriptomes in human airway epithelial cells: commonalities, differences and functional insight from cell lines and primary cells. BMC Med Genomics. 2019;12:29.

30. Leigh R, Mostafa MM, King EM, Rider CF, Shah S, Dumonceaux $\mathrm{C}$, et al. An inhaled dose of budesonide induces genes involved in transcription and signaling in the human airways: enhancement of anti- and proinflammatory effector genes. Pharmacol Res Perspect. 2016;4(4):e00243.

31. Heijink IH, Jonker MR, de Vries M, van Oosterhout AJ, Telenga E, Ten Hacken NH, et al. Budesonide and fluticasone propionate differentially affect the airway epithelial barrier. Respir Res. 2016;6(17):2.

32. Ayroldi E, Cannarile L, Migliorati G, Nocentini G, Delfino DV, Riccardi C. Mechanisms of the anti-inflammatory effects of glucocorticoids: genomic and nongenomic interference with MAPK signaling pathways. FASEB J. 2012;26(12):4805-20.

33. Mitre-Aguilar IB, Cabrera-Quintero AJ, Zentella-Dehesa A. Genomic and non-genomic effects of glucocorticoids: implications for breast cancer. Int J Clin Exp Pathol. 2015;8(1):1-10.

34. Mendes ES, Rebolledo P, Campos M, Wanner A. Immediate antiinflammatory effects of inhaled budesonide in patients with asthma. Ann Am Thorac Soc. 2014;11(5):706-11.

35. Mendes ES, Pereira A, Danta I, Duncan RC, Wanner A. Comparative bronchial vasoconstrictive efficacy of inhaled glucocorticosteroids. Eur Respir J. 2003;21(6):989-93.

36. Del Rosso JQ. Topical corticosteroids: examining pharmacologic properties. Dermatologist. 2006;14(2). Available at: http://www. the-dermatologist.com/article/5340. Accessed 14 June 2019.

37. Pedersen S, O'Byrne P. A comparison of the efficacy and safety of inhaled corticosteroids in asthma. Allergy. 1997;52(39 Suppl):1-34.
38. Brattsand R, Thalén A, Roemke K, Källström L, Gruvstad E. Influence of $16 \alpha, 17 \alpha$-acetal substitution and steroid nucleus fluorination on the topical to systemic activity ratio of glucocorticoids. J Steroid Biochem. 1982;16:779-86.

39. Jackson W. Pulmicort international product monograph, Didcot; 2008.

40. Edsbäcker S, Andersson P, Lindberg C, Ryrfeldt A, Thalén A. Metabolic acetal splitting of budesonide. A novel inactivation pathway for topical glucocorticoids. Drug Metab Dispos. 1987;15(3):412-7.

41. Selroos O. A smarter way to manage asthma with a combination of a long-acting $\beta 2$-agonist and inhaled corticosteroid. Ther Clin Risk Manag. 2007;3(2):349-59.

42. Volovitz B. Inhaled budesonide in the management of acute worsenings and exacerbations of asthma: a review of the evidence. Respir Med. 2007;101(4):685-95.

43. Padden J, Skoner D, Hochhaus G. Pharmacokinetics and pharmacodynamics of inhaled glucocorticoids. J Asthma. 2008;45(suppl 1):13-24

44. Bodor N, Buchwald P. Corticosteroid design for the treatment of asthma: Structural insights and the therapeutic potential of soft corticosteroids. Curr Pharm Des. 2006;12(25):3241-60.

45. de Boer AH, Gjaltema D, Hagedoorn P, Frijlink HW. Can 'extrafine' dry powder aerosols improve lung deposition? Eur J Pharm Biopharm. 2015;96:14351.

46. Demoly P, Hagedoorn P, De Boer AH, Frijlink HW. The clinical relevance of dry powder inhaler performance for drug delivery. Respir Med. 2014;108(8):1195-203.

47. Chrystyn H. Is total particle dose more important than particle distribution? Respir Med. 1997;91:17-9.

48. Pritchard JN. The influence of lung deposition on clinical response. J Aerosol Med. 2001;14(suppl 1):19-26.

49. Medicines and Healthcare Products Regulatory Agency (MHRA). Budesonide PL 17901/0246-7, London; 2008.

50. Ellul-Micallef R, Hansson E, Johansson SA. Budesonide: a new corticosteroid in bronchial asthma. Eur J Respir Dis. 1980;61(3):167-73.

51. Field HV, Jenkinson PM, Frame MH, Warner JO. Asthma treatment with a new corticosteroid aerosol, budesonide, administered twice daily by spacer inhaler. Arch Dis Child. 1982;57(11):864-6.

52. Ellul-Micallef R, Johansson SA. Acute dose-response studies in bronchial asthma with a new corticosteroid, budesonide. Br J Clin Pharmacol. 1983;15(4):419-22.

53. Nyholm E, Frame MH, Cayton RM. Therapeutic advantages of twice-daily over four-times daily inhalation budesonide in the treatment of chronic asthma. Eur J Respir Dis. 1984;65(5):339-45.

54. Laursen LC, Taudorf E, Weeke B. High-dose inhaled budesonide in treatment of severe steroid-dependent asthma. Eur J Respir Dis. 1986;68(1):19-28.

55. Johansson SA, Dahl R. A double-blind dose-response study of budesonide by inhalation in patients with bronchial asthma. Allergy. 1988;43(3):173-8.

56. Haahtela T, Järvinen M, Kava T, Kiviranta K, Koskinen S, Lehtonen K, et al. Comparison of a $\beta 2$-agonist, terbutaline, with an inhaled corticosteroid, budesonide, in newly detected asthma. N Engl J Med. 1991;325(6):388-92.

57. Haahtela T, Jarvinen M, Kava T, Kiviranta K, Koskinen S, Lehtonen $\mathrm{K}$, et al. Effects of reducing or discontinuing inhaled budesonide in patients with mild asthma. N Engl J Med. 1994;331(11):700-5.

58. Haahtela T, Selroos O, O'Byrne PM. Revisiting early intervention in adult asthma. ERJ Open Res. 2015;1(1):00022-2015. 
59. Agertoft L, Pedersen S. Effects of long-term treatment with an inhaled corticosteroid on growth and pulmonary function in asthmatic children. Respir Med. 1994;88(5):373-81.

60. Selroos O, Pietinalho A, Löfroos AB, Riska $\mathrm{H}$. Effect of early vs late intervention with inhaled corticosteroids in asthma. Chest. 1995;108(5):1228-34.

61. Agertoft L, Pedersen S. Effect of long-term treatment with inhaled budesonide on adult height in children with asthma. $\mathrm{N}$ Engl J Med. 2000;343(15):1064-9.

62. Thorsson L, Edsbacker S, Conradson TB. Lung deposition of budesonide from Turbuhaler is twice that from a pressurized metered-dose inhaler P-MDI. Eur Respir J. 1994;7(10):1839-44.

63. Busse WW, Chervinsky P, Condemi J, Lumry WR, Petty TL, Rennard S, et al. Budesonide delivered by Turbuhaler is effective in a dose-dependent fashion when used in the treatment of adult patients with chronic asthma. J Allergy Clin Immunol. 1998;101(4 Pt 1):457-63.

64. Shapiro G, Bronsky EA, LaForce CF, Mendelson L, Pearlman D, Schwartz RH, et al. Dose-related efficacy of budesonide administered via a dry powder inhaler in the treatment of children with moderate to severe persistent asthma. J Pediatr. 1998;132(6):976-82.

65. Shapiro G, Mendelson L, Kraemer MJ, Cruz-Rivera M, WaltonBowen K, Smith JA. Efficacy and safety of budesonide inhalation suspension (Pulmicort Respules) in young children with inhaled steroid-dependent, persistent asthma. J Allergy Clin Immunol. 1998;102(5):789-96.

66. Lipworth BJ, Jackson CM. Safety of inhaled and intranasal corticosteroids: lessons for the new millennium. Drug Saf. 2000;23(1):11-33.

67. Edsbacker S, Wollmer P, Selroos O, Borgstrom L, Olsson B, Ingelf J. Do airway clearance mechanisms influence the local and systemic effects of inhaled corticosteroids? Pulm Pharmacol Ther. 2008;21(2):247-58.

68. Issar M, Sahasranaman S, Buchwald P, Hochhaus G. Differences in the glucocorticoid to progesterone receptor selectivity of inhaled glucocorticoids. Eur Respir J. 2006;27(3):511-6.

69. Valotis A, Högger P. Human receptor kinetics and lung tissue retention of the enhanced-affinity glucocorticoid fluticasone furoate. Respir Res. 2007;8(1):54.

70. Allen A, Bareille PJ, Rousell VM. Fluticasone furoate, a novel inhaled corticosteroid, demonstrates prolonged lung absorption kinetics in man compared with inhaled fluticasone propionate. Clin Pharmacokinet. 2013;52(1):37-42.

71. Derendorf H, Meltzer EO. Molecular and clinical pharmacology of intranasal corticosteroids: clinical and therapeutic implications. Allergy. 2008;63(10):1292-300.

72. Ruge CA, Kirch J, Lehr CM. Pulmonary drug delivery: from generating aerosols to overcoming biological barriers-therapeutic possibilities and technological challenges. Lancet Respir Med. 2013;1(5):402-13.

73. Dalby C, Polanowski T, Larsson T, Borgstrom L, Edsbacker S, Harrison TW. The bioavailability and airway clearance of the steroid component of budesonide/formoterol and salmeterol/ fluticasone after inhaled administration in patients with COPD and healthy subjects: a randomized controlled trial. Respir Res. 2009;31(10): 104

74. Suissa S, Patenaude V, Lapi F, Ernst P. Inhaled corticosteroids in COPD and the risk of serious pneumonia. Thorax. 2013;68(11):1029-36.

75. Janson C, Stratelis G, Miller-Larsson A, Harrison TW, Larsson K. Scientific rationale for the possible inhaled corticosteroid intraclass difference in the risk of pneumonia in COPD. Int $\mathrm{J}$ Chron Obstruct Pulmon Dis. 2017;12:3055-64.
76. Kallen A, Thorsson L. Drug disposition analysis: a comparison between budesonide and fluticasone. J Pharmacokinet Pharmacodyn. 2003;30(4):239-56.

77. Van Den Brink KIM, Boorsma M, Jeske Staal-van den Brekel A, Edsbäcker S, Wouters EF, Thorsson L. Evidence of the in vivo esterification of budesonide in human airways. Br J Clin Pharmacol. 2008;66(1):27-35.

78. Brattsand R, Miller-Larsson A. The role of intracellular esterification in budesonide once-daily dosing and airway selectivity. Clin Ther. 2003;23(Suppl C):C28-41.

79. Nave R, Meyer W, Fuhst R, Zech K. Formation of fatty acid conjugates of ciclesonide active metabolite in the rat lung after 4-week inhalation of ciclesonide. Pulm Pharmacol Ther. 2005;18(6):390-6.

80. Hochhaus G. New developments in corticosteroids. Ann ATS. 2004;1:269-74.

81. Miller-Larsson A, Mattsson H, Hjertberg E, Dahlback M, Tunek A, Brattsand R. Reversible fatty acid conjugation of budesonide. Novel mechanism for prolonged retention of topically applied steroid in airway tissue. Drug Metab Dispos. 1998;26(7):623-30.

82. Adcock IM, Chung KF, Caramori G. Inhaled corticosteroids in airways disease. In: Chung KF, Barnes PJ, editors. Pharmacol Ther Airway Dis. 2nd ed. Boca Raton: CRC Press; 2009. p. 162-97.

83. Miller-Larsson A, Jansson P, Runström A, Brattsand R. Prolonged airway activity and improved selectivity of budesonide possibly due to esterification. Am J Respir Crit Care Med. 2000;162(4):1455-61.

84. Tunek A, Sjödin K, Hallström G. Reversible formation of fatty acid esters of budesonide, an antiasthma glucocorticoid, in human lung and liver microsomes. Drug Metab Dispos. 1997;25(11):1311-7.

85. Barnes PJ. Scientific rationale for inhaled combination therapy with long-acting beta2-agonists and corticosteroids. Eur Respir J. 2002;19(1):182-91.

86. Hancox RJ. Interactions between corticosteroids and $\beta 2$-agonists. Clin Rev Allergy Immunol. 2006;31(2-3):231-45.

87. Koziol-White C, Zhang J, Miller-Larsson A, Dainty I, Panettieri R. Budesonide augments formoterol-induced bronchodilation of human small airways within minutes, PA998. Eur Respir Soc Annual Congress, Amsterdam; 2015.

88. Gibson P, Powell H, Ducharme F, Gibson P. Long-acting beta2agonists as an inhaled corticosteroid-sparing agent for chronic asthma in adults and children. Cochrane Database Syst Rev. 2005;2005:CD005076.

89. Hancox RJ, Aldridge RE, Cowan JO, Flannery EM, Herbison GP, McLachlan CR, et al. Randomised trial of an inhaled beta2 agonist, inhaled corticosteroid and their combination in the treatment of asthma. Thorax. 1999;54(6):482-7.

90. Pauwels RA, Lofdahl CG, Postma DS, Tattersfield AE, O'Byrne $\mathrm{P}$, Barnes PJ, et al. Effect of inhaled formoterol and budesonide on exacerbations of asthma. Formoterol and Corticosteroids Establishing Therapy (FACET) International Study Group. N Engl J Med. 1997;337(20):1405-11.

91. Pang L, Knox AJ. Synergistic inhibition by beta2-agonists and corticosteroids on tumor necrosis factor-a-induced interleukin-8 release from cultured human airway smooth-muscle cells. Am J Respir Cell Mol Biol. 2000;23(1):79-85.

92. Roth M, Johnson PRA, Rüdiger JJ, King GG, Ge Q, Burgess $\mathrm{JK}$, et al. Interaction between glucocorticoids and $\beta 2$ agonists on bronchial airway smooth muscle cells through synchronised cellular signalling. Lancet Respir Med. 2002;360:1293-9.

93. Mak JCW, Nishikawa M, Barnes PJ. Glucocorticosteroids increase b2-adrenergic receptor transcription in human lung. Am J Physiol. 1995; 12:L41-6. 
94. Mak JCW, Nishikawa M, Shirasaki H, Miyayasu K, Barnes PJ. Protective effects of a glucocorticoid on downregulation of pulmonary b2-adrenergic receptors in vivo. J Clin Investig. 1995;96:99-106.

95. Aziz I, Lipworth BJ. A bolus of inhaled budesonide rapidly reverses airway subsensitivity and beta2-adrenoceptor down-regulation after regular inhaled formoterol. Chest. 1999; 115(3):623-8.

96. Tan KS, Grove A, McLean A, Gnosspelius Y, Hall IP, Lipworth BJ. Systemic corticosteriod rapidly reverses bronchodilator subsensitivity induced by formoterol in asthmatic patients. Am J Respir Crit Care Med. 1997;156(1):28-35.

97. Aziz I, Lipworth BJ. Airway subsensitivity and $\beta 2$-adrenoceptor downregulation after regular inhaled formoterol. Chest. 1999;115:623-8.

98. Usmani OS, Ito K, Maneechotesuwan K, Ito M, Johnson M, Barnes PJ, et al. Glucocorticoid receptor nuclear translocation in airway cells after inhaled combination therapy. Am J Respir Crit Care Med. 2005;172(6):704-12.

99. Eickelberg O, Roth M, Lörx R, Bruce V, Rüdiger J, Johnson $\mathrm{M}$, et al. Ligand-independent activation of the glucocorticoid receptor by $\beta 2$-adrenergic receptor agonists in primary human lung fibroblasts and vascular smooth muscle cells. J Biol Chem. 1999;274:1005-10.

100. Theophilus A, Moore A, Prime D, Rossomanno S, Whitcher B, Chrystyn H. Co-deposition of salmeterol and fluticasone propionate by a combination inhaler. Int J Pharm. 2006;313(1):14-22.

101. Osterman K, Carlholm M, Ekelund J, Kiviloog J, Nikander K, Nilholm L, et al. Effect of 1 year daily treatment with 400 microg budesonide (Pulmicort Turbuhaler) in newly diagnosed asthmatics. Eur Respir J. 1997;10(10):2210-5.

102. O'Byrne PM, Barnes PJ, Rodriguez-Roisin R, Runnerstrom E, Sandstrom T, Svensson K, et al. Low dose inhaled budesonide and formoterol in mild persistent asthma: the OPTIMA randomized trial. Am J Respir Crit Care Med. 2001;164(8 Pt 1):1392-7.

103. Tattersfield A, Town G, Johnell O, Picado C, Aubier M, Braillon $\mathrm{P}$, et al. Bone mineral density in subjects with mild asthma randomised to treatment with inhaled corticosteroids or non-corticosteroid treatment for two years. Thorax. 2001;56(4):272-8.

104. Szefler SJ. Long-term effects of budesonide or nedocromil in children with asthma. N Engl J Med. 2000;343(15):1054-63.

105. Pauwels RA, Pedersen S, Busse WW, Tan WC, Chen YZ, Ohlsson SV, et al. Early intervention with budesonide in mild persistent asthma: a randomised, double-blind trial. Lancet. 2003;361(9363):1071-6.

106. Pauwels RA, Lofdahl CG, Laitinen LA, Schouten JP, Postma DS, Pride NB, et al. Long-term treatment with inhaled budesonide in persons with mild chronic obstructive pulmonary disease who continue smoking. European Respiratory Society Study on Chronic Obstructive Pulmonary Disease. N Engl J Med. 1999;340(25):1948-53.

107. Maltais F, Ostinelli J, Bourbeau J, Tonnel AB, Jacquemet N, Haddon J, et al. Comparison of nebulized budesonide and oral prednisolone with placebo in the treatment of acute exacerbations of chronic obstructive pulmonary disease: a randomized controlled trial. Am J Respir Crit Care Med. 2002;165(5):698-703.

108. Zetterstrom O, Buhl R, Mellem H, Perpina M, Hedman J, O’Neill $\mathrm{S}$, et al. Improved asthma control with budesonide/formoterol in a single inhaler, compared with budesonide alone. Eur Respir J. 2001;18(2):262-8.

109. Tunceli O, Williams SA, Kern DM, Elhefni H, Pethick N, Wessman C, et al. Comparative effectiveness of budesonide-formoterol combination and fluticasone-salmeterol combination for asthma management: a United States retrospective database analysis. J Allergy Clin Immunol Pract. 2014;2:719-26.
110. Palmqvist M, Persson G, Lazer L, Rosenborg J, Larsson P, Lotvall J. Inhaled dry-powder formoterol and salmeterol in asthmatic patients: onset of action, duration of effect and potency. Eur Respir J. 1997;10(11):2484-9.

111. Calverley PM, Boonsawat W, Cseke Z, Zhong N, Peterson S, Olsson H. Maintenance therapy with budesonide and formoterol in chronic obstructive pulmonary disease. Eur Respir J. 2003;22(6):912-9.

112. Szafranski W, Cukier A, Ramirez A, Menga G, Sansores R, Nahabedian S, et al. Efficacy and safety of budesonide/formoterol in the management of chronic obstructive pulmonary disease. Eur Respir J. 2003;21(1):74-81.

113. Rennard SJ, Tashkin DP, McElhattan J, Goldman M, Ramachandran S, Martin UJ, et al. Efficacy and tolerability of budesonide/ formoterol in one hydrofluoroalkane pressurized metered-dose inhaler in patients with Chronic Obstructive Pulmonary Disease. Drugs. 2009;69(5):549-65.

114. Tashkin DP, Rennard SJ, Martin P, Ramachandran S, Martin UJ, Silkoff PE, et al. Efficacy and safety of budesonide and formoterol in one pressurized metered-dose inhaler in patients with moderate to very severe Chronic Obstructive Pulmonary Disease. Drugs. 2008;68(14):1975-2000.

115. Ferguson GT, Tashkin DP, Skärby T, Jorup C, Sandin K, Greenwood M, et al. Effect of budesonide/formoterol pressurized metered-dose inhaler on exacerbations versus formoterol in chronic obstructive pulmonary disease: The 6-month, randomized RISE (Revealing the Impact of Symbicort in reducing Exacerbations in COPD) study. Respir Med. 2017;132:31-41.

116. Larsson K, Janson C, Lisspers K, Jorgensen L, Stratelis G, Telg $\mathrm{G}$, et al. Combination of budesonide/formoterol more effective than fluticasone/salmeterol in preventing exacerbations in chronic obstructive pulmonary disease: the PATHOS study. J Intern Med. 2013;273(6):584-94.

117. Blais L, Forget A, Ramachandran S. Relative effectiveness of budesonide/formoterol and fluticasone propionate/salmeterol in a 1-year, population- based, matched cohort study of patients with chronic obstructive pulmonary disease (COPD): Effect on COPD-related exacerbations, emergency department visits and hospitalizations, medication utilization, and treatment adherence. Clin Ther. 2010;32(7):1320-8.

118. Seberova E, Andersson A. Oxis (formoterol given by Turbuhaler) showed as rapid an onset of action as salbutamol given by a pMDI. Respir Med. 2000;94(6):607-11.

119. Partridge MR, Schuermann W, Beckman O, Persson T, Polanowski T. Effect on lung function and morning activities of budesonide/formoterol versus salmeterol/fluticasone in patients with COPD. Ther Adv Respir Dis. 2009;3(4):1-11

120. Welte T, Miravitlles M, Hernandez P, Eriksson G, Peterson S, Polanowski T, et al. Efficacy and tolerability of budesonide/formoterol added to tiotropium in patients with chronic obstructive pulmonary disease. Am J Respir Crit Care Med. 2009;180(8):741-50.

121. Cazzola M, Santus P, Di Marco F, Carlucci P, Mondoni M, Matera MG, et al. Onset of action of formoterol/budesonide in single inhaler vs. formoterol in patients with COPD. Pulm Pharmacol Ther. 2004;17(3):121-5.

122. Lötvall J, Ankerst J. Long duration of airway but not systemic effects of inhaled formoterol in asthmatic patients. Respir Med. 2008;102(3):449-56.

123. Palmqvist M, Arvidsson P, Beckman O, Peterson S, Lotvall J. Onset of bronchodilation of budesonide/formoterol vs salmeterol/fluticasone in single inhalers. Pulm Pharmacol Ther. 2001;14(1):29-34.

124. Ankerst J. Combination inhalers containing inhaled corticosteroids and long-acting beta2-agonists: improved clinical 
efficacy and dosing options in patients with asthma. J Asthma. 2005;42(9):715-24.

125. Barnes PJ. Corticosteroid resistance in patients with asthma and chronic obstructive pulmonary disease. J Allergy Clin Immunol. 2013;131(3):636-45.

126. Partridge MR, van der Molen T, Myrseth SE, Busse WW. Attitudes and actions of asthma patients on regular maintenance therapy: the INSPIRE study. BMC Pulm Med. 2006;13(6):13.

127. Price D, Fletcher M, van der Molen T. Asthma control and management in 8,000 European patients: the REcognise Asthma and LInk to Symptoms and Experience (REALISE) survey. NPJ Prim Care Respir Med. 2014;12(24):14009.

128. Rabe KF, Atienza T, Magyar P, Larsson P, Jorup C, Lalloo UG. Effect of budesonide in combination with formoterol for reliever therapy in asthma exacerbations: a randomised controlled, double-blind study. Lancet. 2006;368(9537):744-53.

129. McKeever T, Harrison TW, Hubbard R, Shaw D. Inhaled corticosteroids and the risk of pneumonia in people with asthma: a case-control study. Chest. 2013;144(6):1788-94.

130. Andrejak C, Nielsen R, Thomsen VO, Duhaut P, Sorensen HT, Thomsen RW. Chronic respiratory disease, inhaled corticosteroids and risk of non-tuberculous mycobacteriosis. Thorax. 2013;68(3):256-62.

131. Singh S, Loke YK. Risk of pneumonia associated with long-term use of inhaled corticosteroids in chronic obstructive pulmonary disease: a critical review and update. Curr Opin Pulm Med. 2010;16(2):118-22.

132. Brassard P, Suissa S, Kezouh A, Ernst P. Inhaled corticosteroids and risk of tuberculosis in patients with respiratory diseases. Am J Respir Crit Care Med. 2011;183(5):675-8.

133. Tashkin DP, Murray HE, Skeans M, Murray RP. Skin manifestations of inhaled corticosteroids in COPD patients: results from Lung Health Study II. Chest. 2004;126(4):1123-33.

134. Sheffer AL, Silverman M, Woolcock AJ, Díaz PV, Lindberg B, Lindmark B. Long-term safety of once-daily budesonide in patients with early-onset mild persistent asthma: results of the Inhaled Steroid Treatment as Regular Therapy in Early Asthma (START) study. Ann Allergy Asthma Immunol. 2005;94(1):48-54.

135. Agertoft L, Pedersen S. Bone mineral density in children with asthma receiving long-term treatment with inhaled budesonide. Am J Respir Crit Care Med. 1998;157(1):178-83.

136. Hughes JA, Conry BG, Male SM, Eastell R. One year prospective open study of the effect of high dose inhaled steroids, fluticasone propionate, and budesonide on bone markers and bone mineral density. Thorax. 1999;54(3):223-9.

137. Tinkelman DG, Bronsky EA, Gross G, Schoenwetter WF, Spector SL. Efficacy and safety of budesonide inhalation powder (Pulmicort Turbuhaler ${ }^{\circledR}$ ) during 52 weeks of treatment in adults and children with persistent asthma. J Asthma. 2003;40(3):225-36.

138. Priftis KN, Papadimitriou A, Anthracopoulos MB, Gatsopoulou E, Fretzayas A, Nicolaidou P, et al. Adrenal function improves in asthmatic children on inhaled steroids: a longitudinal study. Neuroimmunomodulation. 2006;13(1):56-62.

139. Bacharier LB, Raissy HH, Wilson L, McWilliams B, Strunk RC, Kelly HW. Long-term effect of budesonide on hypothalamicpituitary-adrenal axis function in children with mild to moderate asthma. Pediatrics. 2004;113(6):1693.

140. Boorsma M, Andersson N, Larsson P, Ullman A. Assessment of the relative systemic potency of inhaled fluticasone and budesonide. Eur Respir J. 1996;9(7):1427-32.

141. Thorsson L, Edsbacker S, Kallen A, Lofdahl C-G. Pharmacokinetics and systemic activity of fluticasone via Diskus and pMDI, and of budesonide via Turbuhaler. Br J Clin Pharmacol. 2001;52:529-38.
142. Clark DJ, Lipworth BJ. Adrenal suppression with chronic dosing of fluticasone propionate compared with budesonide in adult asthmatic patients. Thorax. 1997;52(1):55-8.

143. Clark DJ, Grove A, Cargill R, Lipworth B. Comparative adrenal suppression with inhaled budesonide and fluticasone propionate in adult asthmatic patients. Thorax. 1996;51(3):262-6.

144. Turpeinen M, Nikander K, Pelkonen AS, Syvänen P, Sorva R, Raitio H, et al. Daily versus as-needed inhaled corticosteroid for mild persistent asthma (The Helsinki early intervention childhood asthma study). Arch Dis Child. 2008;93(8):654-9.

145. Zhang L, Prietsch SO, Ducharme FM. Inhaled corticosteroids in children with persistent asthma: effects on growth. Cochrane Database Syst Rev. 2014;7:CD009471.

146. Agertoft L, Larsen FE, Pedersen S. Posterior subcapsular cataracts, bruises and hoarseness in children with asthma receiving long-term treatment with inhaled budesonide. Eur Respir J. 1998;12(1):130-5.

147. Källén B, Olausson PO. Use of anti-asthmatic drugs during pregnancy. 1. Maternal characteristics, pregnancy and delivery complications. Eur J Clin Pharmacol. 2007;63(4):363-73.

148. Källén B, Olausson PO. Use of anti-asthmatic drugs during pregnancy. 2. Infant characteristics excluding congenital malformations. Eur J Clin Pharmacol. 2007;63(4):375-81.

149. Källén B, Rydhstroem H, Åberg A. Congenital malformations after the use of inhaled budesonide in early pregnancy. Obstet Gynecol. 1999;93(3):392-5.

150. Zaidi S, Chen MJ, Lee DT, Neubart E, Ewing P, Miller-Larsson A, et al. Fetal concentrations of budesonide and fluticasone propionate: a study in mice. AAPS J. 2019;21:53.

151. Morjaria JB, Rigby A, Morice AH. Inhaled corticosteroid use and the risk of pneumonia and COPD exacerbations in the UPLIFT Study. Lung. 2017;195(3):281-8.

152. Tashkin DP, Miravitlles M, Celli BR, Metzdorf N, Mueller A, Halpin DMG, et al. Concomitant inhaled corticosteroid use and the risk of pneumonia in COPD: a matched-subgroup post hoc analysis of the UPLIFT(R) trial. Respir Res. 2018;19(1):196.

153. van den Berge M, Jonker MR, Miller-Larsson A, Postma DS, Heijink IH. Effects of fluticasone propionate and budesonide on the expression of immune defense genes in bronchial epithelial cells. Pulm Pharmacol Ther. 2018;50:47-56.

154. Ek A, Larsson K, Siljerud S, Palmberg L. Fluticasone and budesonide inhibit cytokine release in human lung epithelial cells and alveolar macrophages. Allergy. 1999;54(7):691-9.

155. Provost K, Smith M, Miller-Larsson A, Gudleski G, Sethi S. Bacterial regulation of macrophage pathogen recognition receptors in COPD are differentially modified by budesonide and fluticasone propionate. PLoS One. 2019;14:e0207675.

156. European Medicines Agency. PRAC reviews known risk of pneumonia with inhaled corticosteroids for chronic obstructive pulmonary disease. In: (PRAC) PRAC, editor. London; 2016.

157. Kew KM, Seniukovich A. Inhaled steroids and risk of pneumonia for chronic obstructive pulmonary disease. Cochrane Database Syst Rev. 2014;10(3):CD010115.

158. Lipson DA, Barnacle H, Birk R, Brealey N, Locantore N, Lomas DA, et al. FULFIL Trial: once-daily triple therapy for patients with chronic obstructive pulmonary disease. Am J Respir Crit Care Med. 2017;196(4):438-46.

159. Ferguson GT, Rabe KF, Martinez FJ, Fabbri LM, Wang C, Ichinose M, et al. Triple therapy with budesonide/glycopyrrolate/formoterol fumarate with co-suspension delivery technology versus dual therapies in chronic obstructive pulmonary disease (KRONOS): a double-blind, parallel-group, multicentre, phase 3 randomised controlled trial. Lancet Respir Med. 2018;6(10):747-58. 
160. Sin DD, Tashkin D, Zhang X, Radner F, Sjöbring U, Thorén A, et al. Budesonide and the risk of pneumonia: a meta-analysis of individual patient data. Lancet. 2009;374:712-9.

161. Rennard SI, Sin DD, Tashkin DP, Calverley PM, Radner F. The relationship between COPD severity, inhaled corticosteroid use and the risk of pneumonia. Ann Am Thorac Soc. 2015;12(10):1587-9.

162. Sharafkhaneh A, Southard JG, Goldman M, Uryniak T, Martin UJ. Effect of budesonide/formoterol pMDI on COPD exacerbations: a double-blind, randomized study. Respir Med. 2012;106(2):257-68.

163. Hollis S, Jorup C, Lythgoe D, Martensson G, Regnell P, Eckerwall G. Risk of pneumonia with budesonide-containing treatments in COPD: an individual patient-level pooled analysis of interventional studies. Int J Chron Obstruct Pulm Dis. 2017;12:1071-84.

164. Chung KF. Personalised medicine in asthma: time for action: Number 1 in the Series "Personalised medicine in respiratory diseases" Edited by Renaud Louis and Nicolas Roche. Eur Respir Rev. 2017. https://doi.org/10.1183/16000617.0117-2017.

165. Bateman ED, Reddel HK, O’Byrne PM, Barnes PJ, Zhong $\mathrm{N}$, Keen $\mathrm{C}$, et al. As-needed budesonide-formoterol versus maintenance budesonide in mild asthma. $\mathrm{N}$ Engl $\mathrm{J}$ Med. 2018;378:1877-87.

166. O'Byrne PM, FitzGerald JM, Bateman ED, Barnes PJ, Zhong $\mathrm{N}$, Keen C, et al. Inhaled combined budesonide-formoterol as needed in mild asthma. N Engl J Med. 2018;378:1865-76.
167. Global Initiative for Asthma (GINA). Global strategy for asthma management and prevention. Updated 2019. http://ginasthma. org/. Accessed 14 June 2019.

168. O'Byrne P, Jenkins C, Bateman ED. The paradoxes of asthma management: time for a new approach? Eur Respir J. 2017;50(3):1701103.

169. Pavord I, Beasley R, Agusti A, Anderson G, Bel E, Brusselle $\mathrm{G}$, The Lancet Commissions. After asthma: redefining airways diseases. Lancet. 2018;391(10118):350-400.

170. Bafadhel M, Pavord ID, Russell REK. Eosinophils in COPD: just another biomarker? Lancet Respir Med. 2017;5(9):747-59.

171. Bafadhel M, Peterson S, De Blas MA, Calverley PM, Rennard SI, Richter K, et al. Predictors of exacerbation risk and response to budesonide in patients with chronic obstructive pulmonary disease: a post-hoc analysis of three randomised trials. Lancet Respir Med. 2018;6(2):117-26.

172. Papi A, Vestbo J, Fabbri L, Corradi M, Prunier H, Cohuet G, et al. Extrafine inhaled triple therapy versus dual bronchodilator therapy in chronic obstructive pulmonary disease (TRIBUTE): a double-blind, parallel group, randomised controlled trial. Lancet. 2018;391(10125):1076-84.

173. Lipson DA, Barnhart F, Brealey N, Brooks J, Criner GJ, Day $\mathrm{NC}$, et al. Once-daily single-inhaler triple versus dual therapy in patients with COPD. N Engl J Med. 2018;378:1671-80.

174. Edsbäcker S, Brattsand R. Budesonide fatty-acid esterification: a novel mechanism prolonging binding to airway tissue. Review of available data. Ann Allergy Asthma Immunol. 2002;88:609-16. 